UC- 78

lssued: December 1986

LA- $10890-M S$

DE87 $00476 I$

\title{
TA-2 Water Boiler Reactor Decommissioning (Phase I)
}

\author{
J. C. Elder \\ C. L. Knoell
}

DISCLAIMER

This report was prepared as an account of work sponsored by an agency of the United States employees, makes any warranty, express or implied, nor any agency thereof, nor any of their bility for the accuracy, completeness, or usefulnes, of assumes any legal liability or responsiprocess disclosed, or represents that its use would of any information, apparatus, product, or ence herein to any specific commercial product, process, infringe privately owned rights. Refermanufacturer, or otherwise does not necessarily constitute or service by trade name, trademark, mendation, or favoring by the United States Goventitute or imply its endorsement, recomand opinions of authors expressed herein do not necent or any agency thereof. The views United States Gojernment or any agency thereof. 
ABSTRACT . . . . . . . . . . . . . . . . . . . . . 1

I. INIRODUCTION . . . . . . . . . . . . . . . . . . . . 1

A. Purpose of the Project . . . . . . . . . . . . . . . 1

B. H1story and Description of the Water Boller Reactor . . 2

C. Description of External Structures and Lines . . . . . . 4

D. Project Planning . . . . . . . . . . . . . . . 8

II. OPERATIONAL METHODS . . . . . . . . . . . . . . . . . . 9

A. Radlological Survey Methods . . . . . . . . . . . 9

1. Soll Cleanup Guldelines . . . . . . . . . . . . 9

2. Survey 1ng During Operations . . . . . . . . . . . 12

3. Sampling for Record Furposes . . . . . . . . . . 13

B. Removal Methods ................... . 14

1. Excavation ................. . . 14

2. Contamination Control . . . . . . . . . . 15

3. Waste Disposal . . . . . . . . . . . . . . 16

4. Left Items or Contamination . . . . . . . . . 17

III. SAFETY AND HEALTH PROVISIONS . . . . . . . . . . . . . 17

A. Radiation Protection . . . . . . . . . . . . . 17

B. Safety Methods .................. 18

1. Excavating Safety . . . . . . . . . . . . 18

2. Industrial Hyglene . . . . . . . . . . . . . . 19

3. Traffic Control and Public Access . . . . . . . . 19

C. Administrative Procedures . . . . . . . . . . . 19

IV. FNVIRONMENTAI PROVISIONS . . . . . . . . . . . . . 20

A. Preliminary Survey .................. 2 . .

B. Operational Survey .. . . . . . . . . . . . 21

C. F1na]. Survey . . . . . . . . . . . . . . . . 21

D. Long-Term Survelllance . . . . . . . . . . . . 21

V. RESULTS OF OPERATIONS . . . . . . . . . . . . . . 22

A. Structure and Line Removal . . . . . . . . . . . . 22

1. TA-2-19, The Valve House . . . . . . . . . 22

2. TA-2-62, A Holding Tank . . . . . . . . . . . 22

3. TA-2-32, An Underground Chamber . . . . . . . . 22

4. TA-2-35, A Drainage Basin . . . . . . . . . . 22

5. TA-2-43, A Sept1c Tank . . . . . . . . . . . 26

6. Effluent Lines and Delay Tanks . . . . . . . . . 26

7. TA-2-48, A Condensing Trap ............. 29

B. Other Contaminated Areas at TA-2 . . . . . . . . 36

1. North-Fast Area . . . . . . . . . . . . . 36

2. South-Fast Area ................ . 39

3. North-West Area ............... . 4n

VI. SUMMARY . . . . . . . . . . . . . . . . . . 43

ACKNOWLEDGEMENTS ................... 44

REFERENCES ........................ ... 44

APPEIVIX ....................... 45 
I. Soll Concentration Guldelines (Above Background) Conforming to De Minimus Ievels . . . . . . . . . . . . . . . . . 11

II. Soll Concentration Guldelines ( $\mathrm{pC1} / \mathrm{g}$ Above Background) Based on $500 \mathrm{mrem} / \mathrm{yr}$ Organ Iimit . . . . . . . . . . . . . . 12

\section{FIGURES}

1. TA-2 map showing major exterior stmuctures and lines . . . . 3

2. TA-2-19, the Valve House, with TA-2-62, a holding tank, on the far side . . . . . . . . . . . . . . . . . 5

3. Access hatch to TA-2-32, an underground chamber . . . . . 5

4. The superstructure of TA-2-48, a condensing trap . . . . . . 7

5. Three vlews of TA-2-19, the Valve House, belng demolished . . 23

6. Decomissioning operations at TA-2-32, an underground chamber . 24 6A. Vent1lation supplied during equipnent removal . . . . . 24 6B. Excavation by backhoe to expose the structure . . . . . 24 6C. Reducing the structure by jackhammering . . . . . . . . 25 6D. Removing floor sections by backhoe . . . . . . . . . 25

7. Relocation of plastic pipe carrying infiltrating water from the TA-2-1 basement . . . . . . . . . . . . . . . 27

8. Removal of TA-2-43, a sept1c tank . . . . . . . . . . . 28

9. Removal of TA-2-48, the condensing trap . . . . . . . . . 30

10. Vlews of operations during component removal at TA-2-48, the condensing trap . . . . . . . . . . . . . . . . . 34

11. Areas where surface radioact1ve contamination was removed . . 37

12. Views of the decontaminated area, looking eastward along the stream 
TA-2 WATER BOILFR RFACTOR

DECOMMISSIONING (PHASE I)

by

J. C. Flder and C. L. Knoell

\section{ABSTRACT}

Removal of external structures and underground piping associated with the gaseous effluent (stack) line from the TA-2 Water Boller Reactor was performed as Phase I of reactor decomissioning. Six concrete structures were dismantled and $435 \mathrm{ft}$ of contaminated underground piping was removed. Extensive soll contamination by ${ }^{137}$ Cs was encountered around structure TA-2-48 and in a suspected leach fleld near the stream flowing through Los Alamos Canyon. Efforts to remove all contaminated soll were hampered by infiltrating ground water and heavy rains. Methods, cleanup guldelines, and ALARA decisions used to successfully restore the area are described. The cost of the project was approximately $\$ 320 \mathrm{~K} ; 970 \mathrm{~m}^{3}$ of low-level solid radicactive waste resulted from the cleanup operations.

\section{INTRODUCTION}

A. Purpose of the Project.

The purpose of the TA-2 Water Boller Reactor decormissioning project is to remove all remaining components of the reactor, thereby providing reusable space at the TA-2 site, reducing the hazard of accidental intrusion into contaminated structures, and eliminating the source of possible contamination of the stream bed in Los Alamos Canyon. The results of decommissioning activitles performed in thase I of the project are reported here. Phase I activities were to dismantle the exterior facilities associated with the gaseous effluent (stack) line. Phase II activities scheduled for FY 1989-90 w1ll dismantle the reactor itself, its blological shield, and any remaining equipment or piping. 
The project was sponsored by the Department of Energy (DOE) under the direction of the Surplus Fac1lities Management Program

(SFMP). Its cost was approximately $\$ 320 \mathrm{~K}$ ( $\$ 151 \mathrm{~K}$ in FY 1985 and $\$ 169 \mathrm{~K}$ in FY 1986).

B. H1story and Description of the Water Boller Reactor. The Water Boller Reactor was operated from 1944 to 1974. The reactor was used primarlily as a source of neutrons rather than as an experiment in reactor design. The Water Boller was an $89 \%$ enrlched urantum homogeneous reactor consisting of a 1-ft-diameter stainless steel sphere filled with a water solution of uranyl nitrate and surrounded by a graphite neutron reflector (Bunker 1963). Other major componerits included a concrete h10logical shield, two thermal columns, various access ports, and a gas recombination system. The latter system was added in 1951 to recombine hydrogen and oxygen radiolytically dissociated by reactor operation. The recombination system reduced the hydrogen explosion hazard as well as the quantity of radioactively contamInated gas requiring discharge to atmosphere via the gaseous effluent system. The gaseous effluent system made up most of the piping and structures to be removed in Phase $I$ of the project. During $25 \mathrm{KW}$ operation approximately $220 \mathrm{~cm}^{3} / \mathrm{min}$ of excess gas flowed into the gaseous effluent line. This line ran underground (see Flgure 1) to the top of an adjacent mesa where 1t terminated In a 150-ft stack. A centrifugal blower at the base of the stack provided adequate draft for gas flow in the long pipe. The constituents of the gaseous effluent were air and mixed fission products.

The Water Boller Reactor was shut down, defueled, and placed in a safe shutdown condition in 1974. All systems outs1de the biologlcal shield except for the gaseous effluent line were removed. The control room and reactor room were converted to other purposes. Decomissioning of the reactor, biological shield, other 


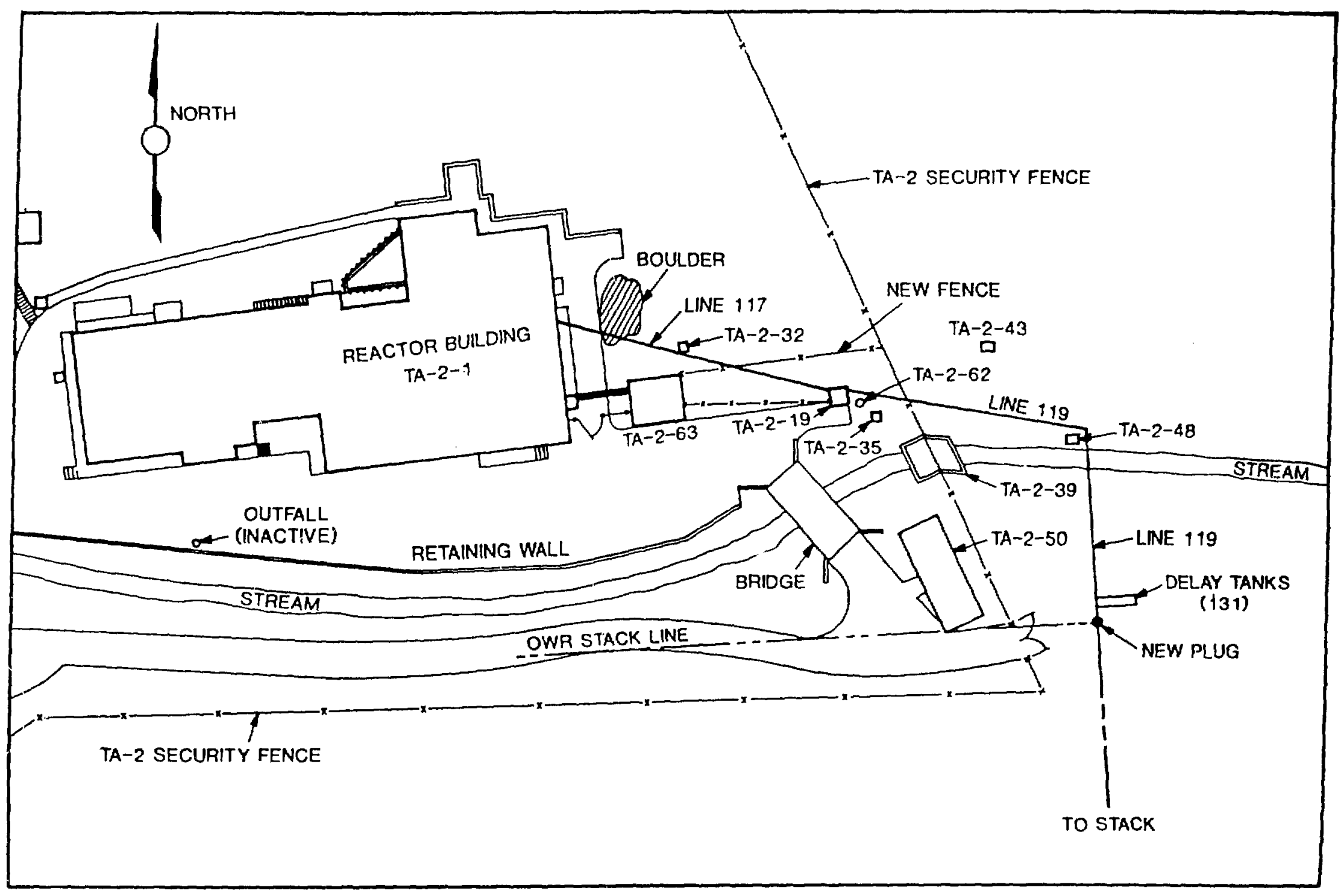

Fig. 1. TA-2 map showing major exterior structures and 11nes. Lines 117 and 119 , structures TA-2-19, TA-2-32, TA-2-35, TA-2-43, TA-2-48, TA-2-62, and the delay tanks were removed by the project. 
components within the blological shield, and a plping pit in the floor of the reactor bullding is scheduled to occur later. This future project $w 111$ be Phase II of the Water Boller Reactor decomissioning and is scheduled to begin in 1989.

C. Description of External Structures and Lines.

Phase I of the TA-2 Water Boller Reactor decommissioning consisted primarlly of the removal of structures TA-2-19, TA-2-32, TA-2-62, a set of delay tanks, TA-2-43, TA-2-48, and the gaseous effluent line. The layout of these components is shown schemat1cally on Figure 1. The major components are described below.

TA-2-19, The Valve House. This heavy reinforced concrete structure was mostly above ground (see Figure 2). Its dimensions were $11 \times 9 \times 10 \mathrm{ft}$ high; 1ts walls were 18 in. thick. Its purpose was to provide valves, pumps, and a shlelded tank where condensate from the gaseous effluent line could be collected and handled. Initial dose rate found in this structure was $70 \mathrm{mR} / \mathrm{hr}$. Lead bricks had been placed to provide local shlelding.

TA-2-62, A Holding Tank. This stainless steel tank (800 L capac1ty; see Flgure 2) was placed adjacent to TA-2-19 to collect the reactor cooling water in case $1 \mathrm{t}$ became contaminated through a breach in one of the cooling colls inside the reactor sphere. The tank was housed Inside a 6- x 4- x 3-ft wooden shed. Radiation levels from the tank and assoclated plplng and valves were not above background.

TA-2-32, An Underground Chamber. Th1s underground concrete chamber was located between Bullding Omega 1 (TA-2-1) and Structure TA-2-19 (see Flgure 3). It provided a shielded collection point for any accidental leakage of the fuel solution from the reactor vessel. A tray below the reactor vessel was connected by pipe to a safe-geometry vessel in TA-2-32. A second vessel was 


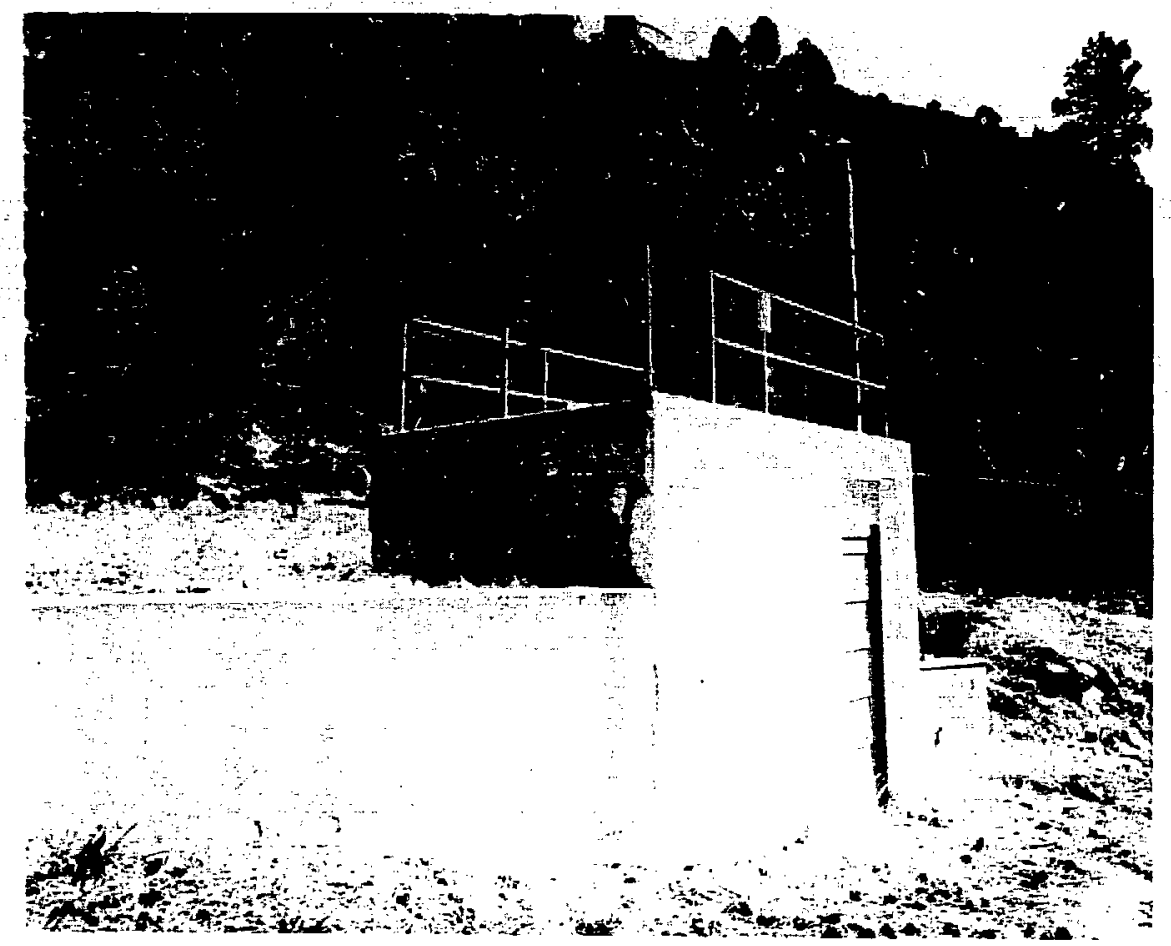

Fig. 2. TA-2-19, the Valve House, with TA-2-62, a holding tank, on the far side.

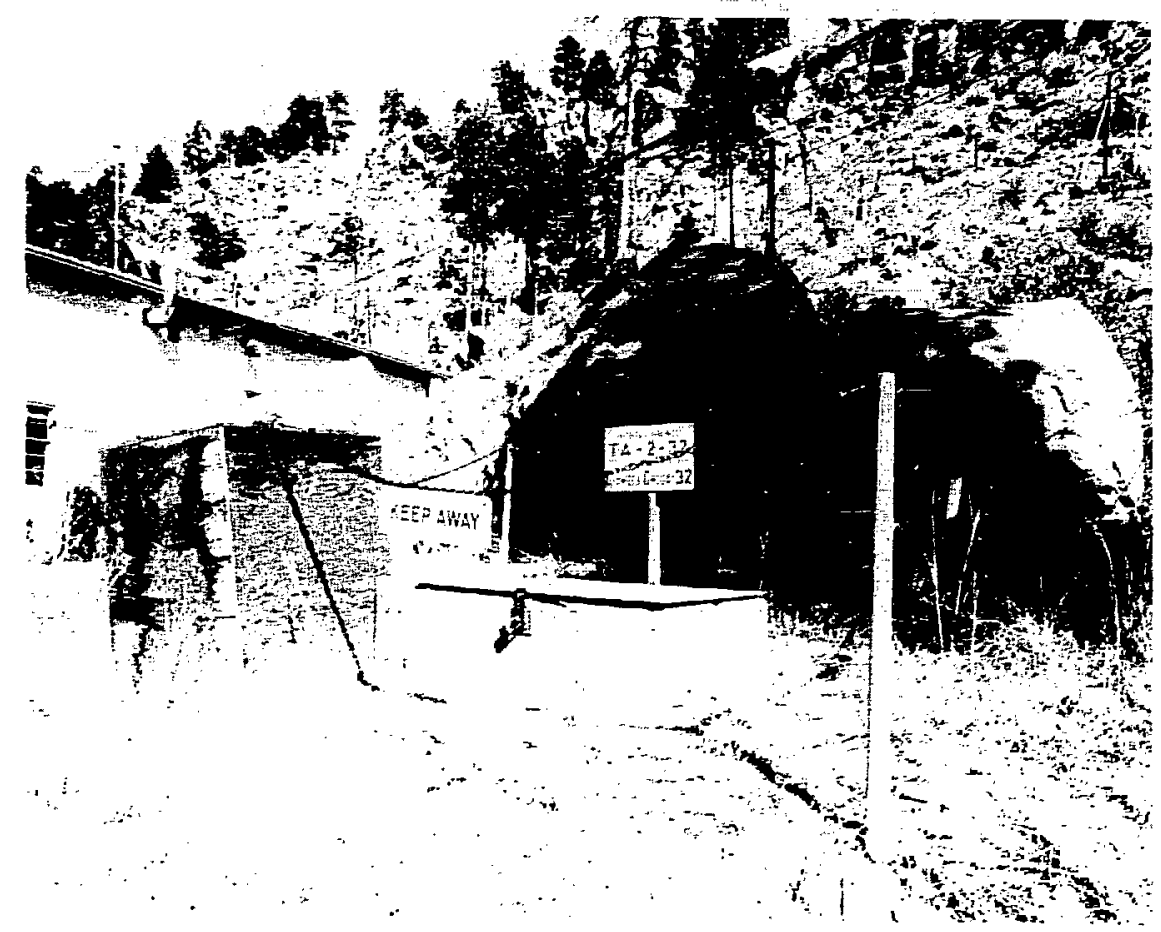

पIE. 3. Access hatoh to TA-2-32, an underground nhamher. TA-P-1, the reactor building, is in the background. 
connected (prior to 1950) by valve and piping to the reactor sphere and could recelve fuel solution dumped as an emergency measure. Ne1ther vessel had been contaminated by any usage. Access to this $13-x$-ft structure was by ladder to the floor, which was approximately $13 \mathrm{ft}$ below ground level. The gaseous effluent line (Line 117 between TA-2-1 and TA-2-19) had no connection with $\mathrm{TA}-2-32$.

TA-2-43, A Sept1c Tank. This concrete sept1c tank served the sanitary sewer needs of TA-2 in the early years but had been disconnected from the sanitary sewer in the $1950 \mathrm{~s}$. It was semlactive in recent years only because spring-fed water leakage Into the basement of $\mathrm{TA}-2-1$ was pumped to 1 t routinely. It was believed that this tank had once been contaminated, although sampling during decomissioning did not detect any residual radioactivity.

TA-2-48, A Condensing Trap. Th1s structure consisted of a concrete manhole superstructure (see Figure 4) and a small-diameter standp1pe which intersected the gascous effluent line (Line 119) at its low point between TA-2-19 and its junction with the Omega West Reactor vent line. Some confusion existed at the time of 1ts removal because a large-dlameter (24-1n.) steel pipe $12 \mathrm{ft}$ long was expected to be under the manhole. Removal operations showed that the 24-1n. pipe had been partially removed earlier (probably in the late 1940s) and a new version (the standpipe) had been installed. As discussed in Section V.A., portions of the orlginal device were also present and figured prominently in removal operations.

TA-2-35, A Drainage Basin (Manhole). This 3-x 4- 3 4-ft concrete structure was located near TA-2-19; 1t was not contaminated.

Line 117. Line 117 was a 4-in. cast-iron pipe through which three smaller 1 ines were passed from TA-2-1 to TA-2-19. The pipe read $20 \mathrm{mR} / \mathrm{hr}$ at contact in the p1t inside $\mathrm{TA}-2-1$; the $1 / 2-1 \mathrm{n}$. stalnless steel gaseous effluent iine inside $1 \mathrm{t}$ read $80 \mathrm{mR} / \mathrm{hr}$ at 


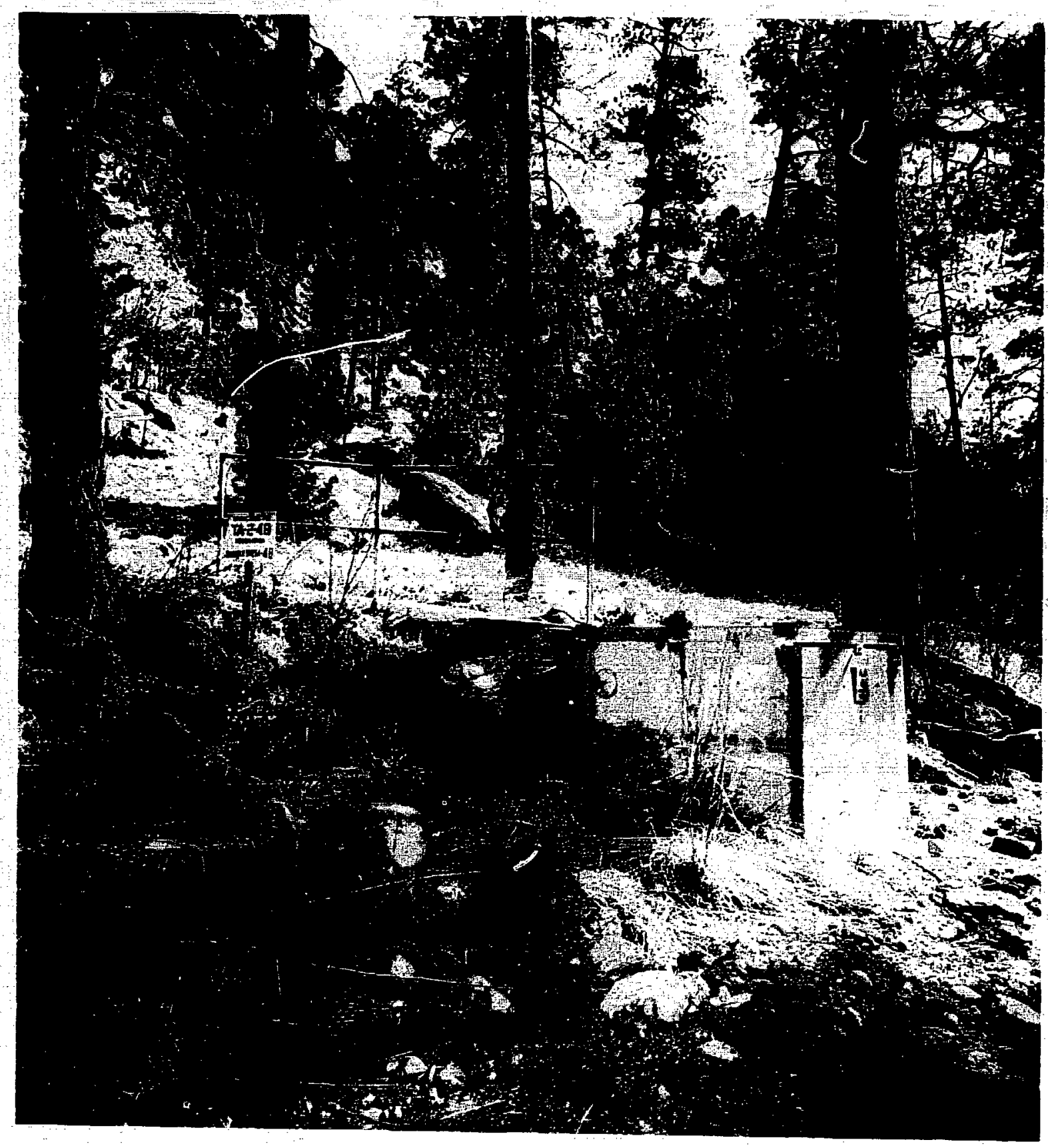

Fg. 4. The supenstructure of TA-2-4, a condensing trap. 
contact. Lead brick and melted paraffin were found surrounding Line 117 in a pit inside TA-2-1 where the line originated. Radiation level in the pit was $20 \mathrm{mR} / \mathrm{hr}$.

Iine 118. Lne 118 was a small-diameter statnless steel line laid in a shallow trench from $\mathrm{TA}-2-19$ to a location near the delay beds (1tem 131). It was probably a temporary gas vent or sampling line.

Ine 119. Line 119 was a 3-1n. stainless steel pipe which carried gaseous effluent from TA-2-19 to the intersection w1th

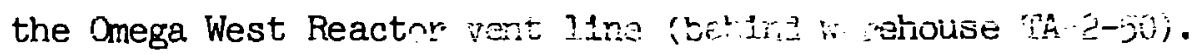

Unnumbered Lines. An unnumbered vitrifled clay pipe (VCP) Iine extended from $T A-2-43$, the sept1c tank, to the stream. Its purpose had been to carry overflow from the septic tank but it apparently hecame plugged same years ago. Ariother clay line in the same area was discovered during soll cleanup operations east of TA-2-48 (see Section V.B).

Item 131, Delay Tanks. The delay tanks were two 12-1n.-diameter stainless steel tanks $20 \mathrm{ft}$ long lylng parallel to each other. The extra volume they added to the effluent line allowed greater decay time for short-lived radionuclides.

\section{Project Planning.}

A project plan for Phase I of the TA-2 Water Boiler decommlssioning was prepared in 1985 by the Laboratory's Radiation Protection Group (HSE-1) and approved by representatives of the following:

HSE-1, the Radiation Protection Group ENG-1, the Construction Group The Zia Company (later Pan Am) 
INC-5, Research Reactor, the Operating froup

HSE-3, the Safety Group

HSE-5, the Industrial Hygiene Group

HSE-8, the Environmental Survelliance Group.

The project plan provided safety requirements, description of the work, expected hazards, and assignments of responsibilities.

Soll cleanup guidelines adopted for the project. were stated and justiffied in the project plan.

\section{OPERATIONAL METHODS}

A. Radiological Survey Methods.

The project involved primarily the total removal of small external structures, underground p1pes, and contaminated soll, rather than the decontamination of walls or other surfaces. The survey methods and soll cleanup guidelines discussed in this section therefore deal primarily with residual ictivity in soll.

1. So1l Cleanup Guldelines. Guldelines for residual radiaactivity concentrations in soll after removal of lines and structures were based on the general princlple of as low as reasonably achievable (ALARA). Under this principle, the primary guidance was to keep any future exposure of employees or the general public to remaining radioactivity to as low a level as technically and economically reasonable. To expedite decision making concerning this principle, de minimus levels of soll contamination and upper-limit concentration guldes were used. De minimus levels are those below which no environmental or physical effect is expected. These levels were recommended by the Laboratory's Environmental Surveillance Group (HSE-8). Establishing de minimus levels addressed the use of unreasonably long sample counting times in quest of continually lower detection limits. The upper limit concentration guides, also recormended by HSE-8, were selected to ensure conformance to the secondary requirement that no member of the public recelve a dose, as a result of 
exposure to residual contamination, exceeding $500 \mathrm{mrem} / \mathrm{yr}$ to any organ of the body. These latter limits were derlved by calculations of potential dose equivalents associated with important radionuclides transported by varlous possible pathways. The derivation of these limits is presented in Append1x B of LA-10821-MS (Elder 1986).

The inftial step in the application of these guidelines was removal of structures and excavation of soll unt1l no abovebackground readings were obtained using beta/gamma survey meters or unt1l 1t was Impractfcal to proceed further (1.e., depth greater than backhoe reach, Interference from obstacles, Interference by ground water, and the like).

Soll samples were obtalned at appropriate representat1ve locations along the bottom and walls of the excavation or from the location where the excavated soll was placed. The number of soll sampling locations was dependent on relative radionuclide levels.

So1l samples were analyzed for varlous const1tuents such as gross alpha, gross beta, or ganma spectrum. Previous sample results were also observed. Sample analysis results were compared to the de minimus guidelines shown in Table I.

If the soll sample results were below the levels given in Table I, the area was considered acceptably free of contam1nation. If soll sample results exceeded the guldelines, additional cleanup was requested and the monitoring and sampling procedures were repeated unt1l the guldelines were met or 1t was determined that further cleanup to the guideIInes was impractical due to safety, economics, or other reasons. Administrative procedures by which ALARA decisions were made are provided in the Appendix. 
SOIL CONCENIRATION GUIDELINESS (ABOVE BACKGROUND)

CONFORMING TO DE MINIMUS LEVFLS

\begin{tabular}{|c|c|c|}
\hline & Surface So1l ${ }^{a}$ & Subsurface So1 ${ }^{\mathrm{b}}$ \\
\hline Gross Alpha & Nondetectable ${ }^{c}$ & $75 \mathrm{pCl} / \mathrm{g}$ \\
\hline Gross Beta & $25 \mathrm{pCl} / \mathrm{g}$ & $75 \mathrm{pCl} / \mathrm{g}$ \\
\hline Extemal Gamma ${ }^{d}$ & $5 \mu R / h$ & $20 \mu R / h$ \\
\hline
\end{tabular}

${ }^{a}$ Surface soll is defined as soll located within $5 \mathrm{ft}(1.5 \mathrm{~m})$ from the surface.

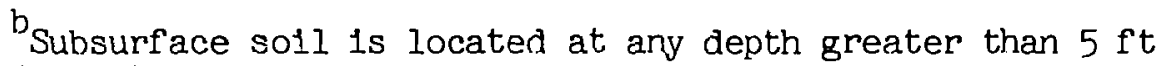
$(1.5 \mathrm{~m})$.

${ }^{\mathrm{c}}$ Detector background plus 3 sigma counting error. $\mathrm{d}_{\text {If }}{ }^{137} \mathrm{Cs}$ is present.

If the de minimus guidelines could not be reasonably met, the measured levels would be compared to those in Table II, which glves the upper limit concentration guldelines based on the $500 \mathrm{mrem} / \mathrm{yr} d \mathrm{~d} \geqslant 1 \mathrm{milt}$. The concentrations in Table II are based on very conservative sceriarios and as such would not be construed as absolute limits. Conservative assumptions made in the scenarios might be very different from the fleld situation encountered. Thus, flexiblilty was used in applying the guidelines and consideration was given on a case-by-case basis to factors such as the extent, depth, and location of the contamination zone, the radionuclides present and their concentrations, the nature of the contaminated soll, and the safety, economic, and operational impact of further decontamInation. Taking these factors into account and using Table II guidelines as reference points, decisions were made as to whether the contamination would result in a $500 \mathrm{mrem} / \mathrm{yr}$ dose to any organ of any member of the public. Decontamination 
continued until it was felt that the occurrence of the 500 $\mathrm{mrem} / \mathrm{yr}$ dose was very Improbable.

TABLE II

SOIL CONCENTRATION GUIDELINES ( $\mathrm{pC1/g}$ ABOVE BACKGROUND) BASED ON $500 \mathrm{mrem} / \mathrm{yr}$ ORGAN LIMIT

\begin{tabular}{|c|c|c|}
\hline Radionuclide & Surface Soll $^{a}$ & Subsurface So11 \\
\hline $241_{A m}$ & 50 & 600 \\
\hline${ }^{241} \mathrm{Pu}^{\mathrm{b}}$ & 1670 & 20400 \\
\hline $239-240 \mathrm{Pu}$ & 200 & 1900 \\
\hline${ }^{238} \mathrm{Pu}$ & 350 & 3200 \\
\hline${ }^{238} \mathrm{U}$ & 80 & 960 \\
\hline${ }^{235} \mathrm{U}$ & 80 & 960 \\
\hline 234 & 80 & 960 \\
\hline${ }^{137} \mathrm{Cs}$ & 80 & 960 \\
\hline $90_{\mathrm{Si}^{n}}$ & 100 & 1200 \\
\hline $3_{\mathrm{H}} \mathrm{c}$ & 8870 & 120000 \\
\hline
\end{tabular}

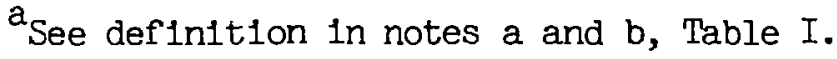

b241 Pu limit derived from the ${ }^{241}$ Am concentration.

${ }^{\mathrm{c}} \mathrm{In} \mathrm{pCl} / \mathrm{ml}$ of soll molsture.

2. Surveying During Operations. A trained health physics technician provided continuous survelllance of excavation and waste removal work. For detection of ${ }^{137} \mathrm{Cs}$ radioactivity in so1l, the technician was equipped with a portable Iudlum Model 3 counting rate meter with a shielded end-window Gelger-Mueller (GM) detector and a National Nuclear HM-3 NaI scintillation detector. The $0.662-\mathrm{MeV}$ photon emitted by ${ }^{137} \mathrm{Cs}$ has adequate range both in air and in soll to be readily detected. The scintillation detector was sensitive enough to allow location of rotspots by walking surveys with the instrument at waist level. 
Monitoring of equipment surfaces and personnel was accomplished by end-window (MM detectors for beta/ gamma radiation and air proportional counters for alpha radiation. These instruments received normal servicing and calibration checks through the Laboratory's health physics instrumentation section.

3. Sampling for Record Purposes. The Fnvironmental Surveillance Group obtained soil samples at intervals selected to provide representative samples from the bottom and walls of the excavation or from excavated soll. Soll samples were more numerous in locations where radionuclide activity had been found or was expected.

Quality control procedures for soll sampling included the following:

- radiochemical analysis of selected soll samples,

- duplicate and split samples consisting of approximately $10 \%$ of the total number of samples, and

- Tally calibration checks of gross alpha and gross beta counting instruments with soll samples spiked with ${ }^{239} \mathrm{Pu}$ and ${ }^{137} \mathrm{Cs}$, respectively.

The primary laboratory alpha and beta/ganma counting instruments were 10-cm-dlameter ZnS scintillation detectors equipped with single-channel analyzers. Soll samples were placed in plastic bags and manually worked to break up soll chunks. Approximately $75 \mathrm{~g}$ of soll was placer in 88-mm-diameter $\times 13-m m$-deep plast1c petri dishes. The samples were dried in a microwave oven, allowed to cool, and counted for 5 minutes. This procedure allowed detection above background of approximately $25 \mathrm{pCl} / \mathrm{g}$ alpha activity and $8 \mathrm{pCl} / \mathrm{g}$ beta/ ganma ictivity. Background and calibration counts were performed dally. 


\section{B. Removal Methods.}

1. Excavation. A drawing search and walkthrough by all involved parties preceded decormissioning. The construction engineer prepared a work order which described the scope of work, location, cost estimate, manpower and equipment needed, and special safety requirements of the job. Personnel safety methods are discussed in Section III.B. The work order recelved approval from representatives of the Laboratory, DOE, and the Z1a Company (later Pan Am).

A policy was followed that known underground utility lines near the pipe or structure be exposed by hand digging before machine excavation started. Machine excavation was typically performed by one of two hydraulically operated excavators:

- LHebherr excavator $-1.3 \mathrm{yd}^{3}$ bucket w1th 25 -ft reach;

○ John Deere backhoe $-0.25 \mathrm{yd}^{3}$ bucket with $16-\mathrm{ft}$. reach.

Excavated soll determined to be clean was stockplled for reuse as backf1ll materlal. Contaminated soll was loaded directly onto plastic-lined, tarpaulin-covered dump trucks for transport to the Solld Radioactive Waste Management Site $(\mathrm{TA}-54)$.

Excavations were backfilled w1th their own excavated materlal when practicable. Compaction at depths below $5 \mathrm{ft}$ was accomplished hydraulically, by tamping with the backhoe bucket, or by a combination of methods depending on backfill material. From the 5-ft depth to the surface, compaction was by hand tamper, trench roller, or front-end loader depending on the area. The flour-like consistency of crushe 1 tuff* required liberal wetting as the backfilled area was being compacted.

*Tuff. is rock composed of compacted volcanic ash and dust. 
P1pe removal procedures were dictated somewhat by the type of pipe being removed. Vitrified clay pipe between TA-2-43 and the stream was broken by the backhoe bucket and removed directly with soll. Steel pipe was removed by holsting a length out of the trench, cutting the pipe into appropriate lengths, taping both ends, and loading each section onto a truck. This operation did not require entry of personnel into the trench. Pipe cutting was accomplished by portable (saber) saw.

Plpe pulling, a technique which can be used with elther steel or plastic plpe, was used on a few occasions. Plpe pulling permits removal of sections of pipe (up to $300 \mathrm{ft}$ long) without trenching down to the pipe except at each end of the section. A cable is fed through the pipe, connected to the cable pulling device at one end, and is connected to the backhoe boom at the other end. Repeated short pulls with the boom and cutting of the pipe at appropriate intervals permits removal of the pipe at lower cost due to reduced excavation.

Structure removal was made in sections where possible. Several structures were removed whole, but in one case (TA-2-19) 1t was necessary to jackhammer all but the floor of the structure into rubble. Specific removal procedures are discussed further in Section V.A.

2. Contamination Control. Occasions with highest potential for spread of contamination occurred when pipes were cut, when pipes and soll were lifted from the excavation, or when soll and other material were transported by truck. Contamination control during removal operations involved wrapping and sealing contaminated materials, controlling airborne contamination by water spray, draining or soaking up contaminated liquids, and the like. Previous experience at Los Alamos and elsewhere provided useful methods by which contamination was retained in the desired location. Plastic bags or trays were 
used to contaln any liquid from a plpe as it was being cut. Both ends of cut sections of pipe were bagged and taped before transport. This was not the case with clay pipe, which was broken by the backhoe and removed with the so:1 and base coarse under 1 .

Water spray was used to suppress dust generation during excavation, depending on soll conditions and the level of contamination. At TA-2, the soll molsture was generally high throughout the project (e1ther by rainfall or ground water), maklng spray seldom necessary.

Decontamination of equipment such as the backhoes or dump trucks was seldom necessary. Backhoes were monitored before moving away from the work site to avold tracking or spreading. Dump trucks were routinely monitored before departing the works1te and TA-54.

Detalled description of decontamination of specific areas is provided in Section V.

3. Waste Disposal. The contaminated material removed by the project was transported to the Solid Radioactlve Waste Management Site (TA-54) by dump trucks with plastic-lined and covered beds. The loads were routinely $5 \mathrm{~m}^{3}$ volume. Loaci data were summarlzed from Radioactive Solid Waste Disposal records (RSWD load tickets) which accompanled every load and described the waste in the load. An estimate of activity in loads of soll, pipe, and debris was made. Activity within a length of pipe was estimated by taking several readings with a detector probe, converting average count rate to activity under the probe and multiplying by appropriate probe-to-pipe surface area ratios for the length and diameter of the pipe. The method assumed uniform deposition along the length of the plpe. 
The waste from TA-2 was deposited in trenches at TA-54 Area G. Waste management operations at Area $G$ are described in HSE-7 Standard Operating Procedures and operating Instructions. Retrievable waste ( $>100 \mathrm{nCl} / \mathrm{g}$, TRU waste;, had the project encountered any, would have been packaged for storage in sealed shafts.

4. Left Items or Contamination. Occasionally, a contaminated 1tem or soll contamination was left in place because of interferences such as excessive depth or ground water. These 1tems or contamination wculd be left only after ALARA dec1slons were made and sultable documentation was prepared. Locations where contamination was left are discussed Ind1vidually in Section $V$. The basic procedure for arriving at an ALARA decision is discussed in the Append1x.

A monument, sign, or other marker was not Installed at the site of left contamination. The contamination was generally left in a location not likely to be disturbed or in a cond1tion not likely to cause a detectable hazard if disturbed.

\section{SAFETY AND HEALTH PROVISIONS}

A. Radiation Protection.

The Laboratory's Radiation Protection Group (HSE-1) provided continuous survelllance of excavating and waste removal operations by a trained health protection technician. Special requirements for radiation protection of workers were specified under the Laboratory practice of 1ssuing Speclal Work Permit for Radiation Work (see RWP, Health and Safety Manual, Administrative Requirements $1-3$ and 3-1). The RWP was inttlated by the project technical manager and completed by HSE-1 personnel, once expected conditions had been reviewed. Anticontamination clothing, respiratory protection, and a1r sampling were provided as necessary. Experlence w1th typlcal excavation and removal work showed very little measurable contamination was made a1rborne nor was 1t likely that significant soll contamination would be encountered without early detection by fleld instrumentation. 
Personnel monitoring included normal monthly radiation badge dosimetry and bloassay analysis of urine specimens and in vivo counting on an annual basis. Continuous air sampling in the work area was not considered necessary due to previous experience. Occasional air sampling, was performed in areas where contamination was signiflcantly above background. A1r samples were sent to the Health Physics Analysis Lab (HSE-1) ior analys1s of gross alpha and gross beta/gamma activity. Resplratory protection would be required (full-face resplrators) whenever high soll activity was sicountered; this condition was not encountered on the reject. Respirators were fitted to each worker by the Industrial Hyglene Group (HSE-5).

Nasal smears were taken foilowing dusty operations and checked for beta/ganma activity. None of the smears approached the action level of 5000 dpm beta/gamma at which an occurrence report would be required.

B. Safety Methods.

No lost time accidents occurred in the project. Special safety features of the project are discussed below.

1. Excavating Safety. Most of the excavating in the project could be accomplished with adequate slope on the excavation to preclude cave-1n. The possibility of cave-in in deeper excavations would require issue of special work permits and the following safety practices to allow personnel entry:

- shoring rules were followed in accordance with OSHA regulations (OSHA 1979);

- approved shoring or trench wall slopling methods were applied whenever personnel access to trenches deeper than $5 \mathrm{ft}$ was needed. 
2. Industrial Hyglene. One occasion required personnel entry Into a confined space (TA-2-32). The zia Safety office provided monttoring for safely breathable atmosphere.

Hazardous materials were encountered once in the removal operation. The unexplained presence of a small amount of mercury required cleanup under controlled conditions.

3. Traffle Control ard Public Access. TA-2 is a controlled area on DOE-owned land. Access control to the work site was provided by normal security procedures.

C. Administrative Procedures.

Prior to excavation and removal, a series of steps was followed to insure that all involved parties had provided needed input. Administrative procedures were followed to:

- prepare a project plan and obtain concurrence within the DOE LAAO - Laboratory - Zia (later Pan Am) organizations;

o obta1n authorization from DOE through DOE-AL to remove the lines and structures included in the project;

- In1tiate work orders as needed to inform and obta1n approvals from operating groups affected by the project and coordinate efforts of the participating groups (HSE-1, HSE-7, HSE-8, ENG-1, INC-5, and the 21a Company [later Pan Am]);

- schedule personnel and equipment;

- provide preliminary surveys and research to avold Interference with existing utilities or operations to the greatest extent possible; 
- provide complete documentation of operations such as manpower use, 1tems removed, location of left 1tems, waste volumes, and the like;

- reach informed, supportable ALARA decisions;

- provide complete documentation at the end of project, particularly as-left conditions and updating data in the DOE Real Property Inventory System.

The key administrative procedural items are summarized as follows:

- Safety policies, guidelines, and instructions in the Los Alamos Health and Safety Manual were applied to all the activities. These govern health physics monitoring, Industrial safety, and enviromental monitoring matters.

- Authorization to perform removal operations was obtained in advance through DOE, Laboratory, and Zia Company (later Pan Am) channels.

- The removal operations were conducted in a manner consistent with the ALARA princlple viewed from the aspect of the worker and the environment (left 1tems or soll contamination).

- Preliminary work was expended to avold disruption of normal Laboratory operations or possible hazard to workers.

IV. ENVIRONMENTAL PROVISIONS

\section{A. Preliminary Survey.}

The long history of operation of the Water Boller Reactor left the passibility of contamination spread at TA-2. Its proximity to a stream that eventually runs offsite approximately $6.4 \mathrm{~km}$ 
away makes any environmental contamination at TA-2 of particular interest. A preliminary survey was conducted by the Iaboratory's Envirormental Survelliance Group (HSE-8) in an area from TA-2-1, the reactor building, along the path of the gaseous effluent line to TA-2-48, then southward across the stream, and upslope toward the exhaust stack on the mesa top. The preliminary survey was made by soll sampling at 20-ft intervals (grid) on June 28, 1985. Beta/garma activity no higher than $66 \mathrm{pC1} / \mathrm{g}$ was detected east of TA-2-1. As discussed in Section V.B., this preliminary survey did not include the area east of TA-2-48 found later to be more highly contaminated.

B. Operat1oral Survey.

Operational surveys were provided by HSE- 8 on an as-needed basis to allow decontaminated areas to be hackfilled at intermediate points in the operation. HSE- 8 glso provided extensive instrumental field surveys in areas near the stream where the possibility of contamination spread was particularly acute. These surveys were conducted using an HM-3 scintillation detector to locate hotspots. Cleanup of the hot:spots was verifled by soll sampling as discussed in Section II.A.3.

C. Flnal Survey.

A final survey of the TA-2 area was conducted hy instrumental surveying and soll sampling. The results of the flnal survey are Included in Sectio- V.B.

D. Long-Term Surveillance.

HSE-8 will continue to provide long-term environmental survelllance in the form of water sampling (both surface water samples from the stream and well samples from Well No. LA-0-2) and soll and sediment sampling (Station LA-0-1, $100 \mathrm{~m}$ downstrean of TA-2). These sampling lccations are shown in Los Alamos Environmental Survelllance Report for 1985, LA-10721-ENV pages 160 and 170. The 1985 report shows ${ }^{137} \mathrm{Cs}$ levels in water at $\mathrm{LA}-0-1$ to be $47 \pm$ $48 \times 10^{-9} \mu \mathrm{Cl} / \mathrm{m} \ell$ on $4 / 9 / 85$ and $-12 \pm 35 \times 10^{-9} \mu \mathrm{Cl} / \mathrm{ml}$ on $9 / 19 / 85$ 
and ${ }^{137} \mathrm{Cs}$ levels to be $0.16 \pm 0.08 \mathrm{pC1} / \mathrm{g}$ in so1l and sediment at LA-0-1. Any significant increase in these quantities will prompt a review of conditions at $T A-2$.

\section{RESULTS OF OPERATIONS}

\section{A. Stmucture and Line Removal.}

Brlef descriptions of each structure and line removed are contained in Section $I$. The following sections provide a brief description of the removal operation and its results.

1. TA-2-19, The Valve House. TA-2-19 was removed by Jackhammering and cutting rebar with a gas torch as it was exposed. Personnel wore dust respirators, ear plugs, and pocket dosimeters for this operation. The structure was wetted to reduce dust. FIgure $5 \mathrm{~A}, \mathrm{~B}$, and $\mathrm{C}$ show TA-2-19 at several stages of removal. Line 119 was removed from under the floor; it showed a contact reading of $35 \mathrm{mR} / \mathrm{hr}$. No soll contamination was detected under the floor.

2. TA-2-62, A Holding Tank. Water found in this tank was sampled and found to be uncontaminated. It was drained and removed as a unit. Soll samples taken under the tank were low but positive ( $63 \mathrm{pCl} / \mathrm{g})$. Th1s soll was removed to cstablish de minimus surface levels (less than $25 \mathrm{pCl} / \mathrm{g}$ ).

3. TA-2-32, An Underground Chamber. TA-2-32 was treated as a confined space where atmosphere testing and additional ventilation were provided. Deconmissioning operations Included Jackhammering, cutting rebar, and wall removal in large sections by machine as shown in Flgure $6 \mathrm{~A}, \mathrm{~B}, \mathrm{C}$, and D. Removal required a large excavation and backfilling. № radioactivity was detected in the soil under the structure. Soll wetting alded the compaction of the backilll.

4. TA-2-35, A Drainage Basin. Removal of this drainage basin (manhole) was accomplished as one plece. Soll sampling showed no activity under the structure. 

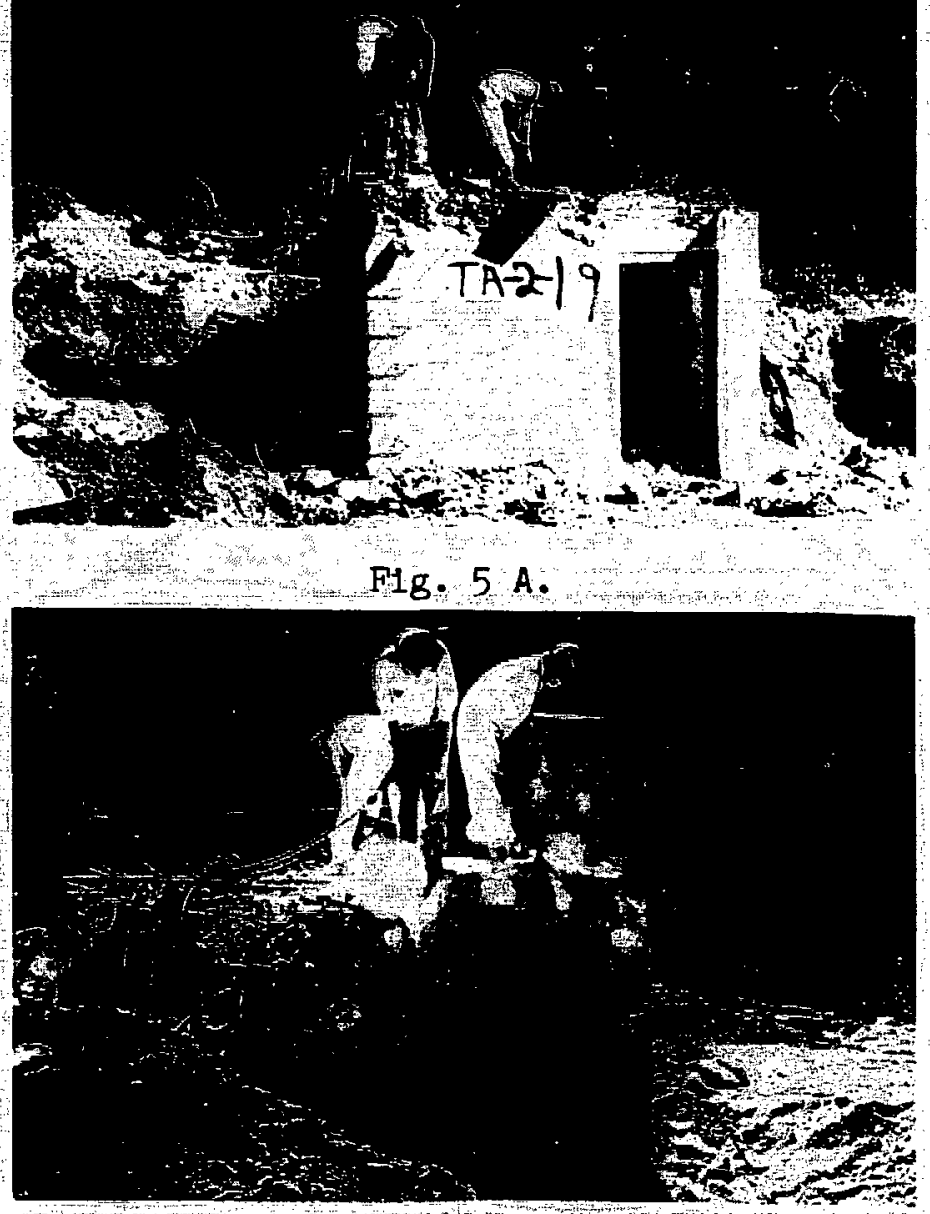

Fig. 5 B.

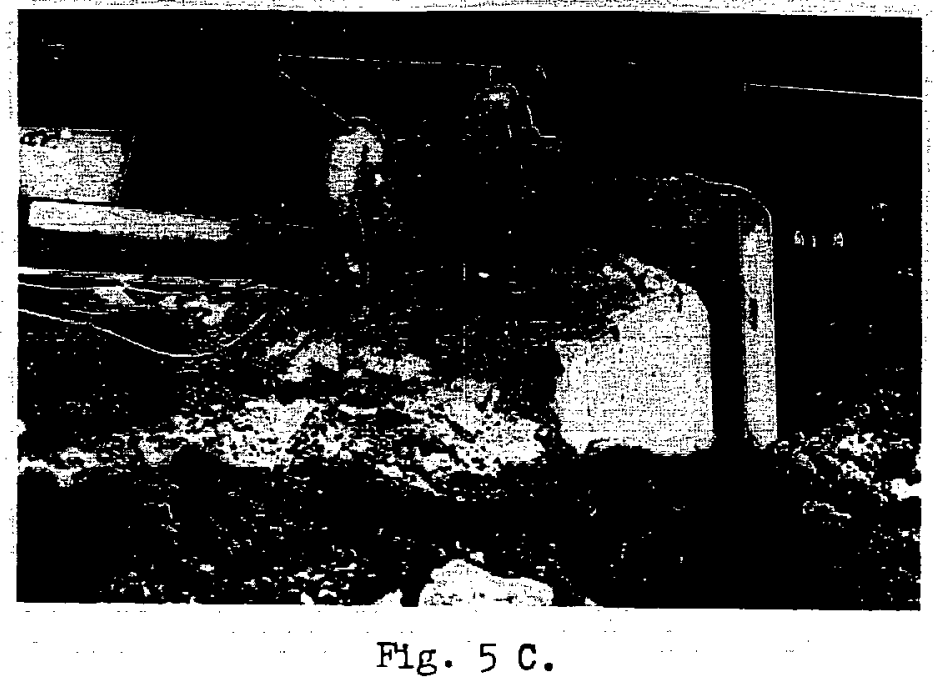

Fig. 5. Three views of TA-2-19, the Valve House being demolished. 


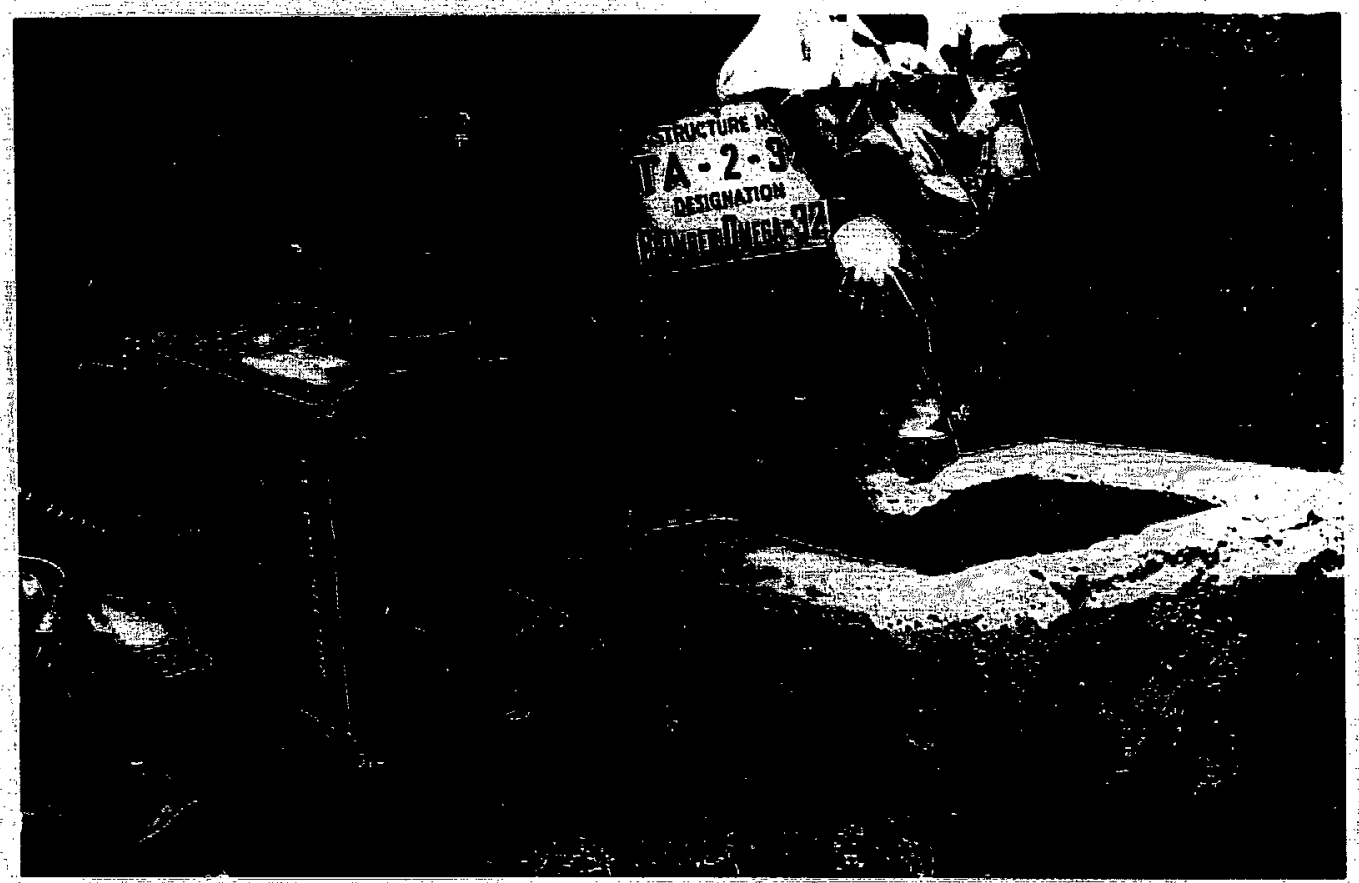

FIg. $6 \mathrm{~A}$. Ventilation supplied during equipment removal.

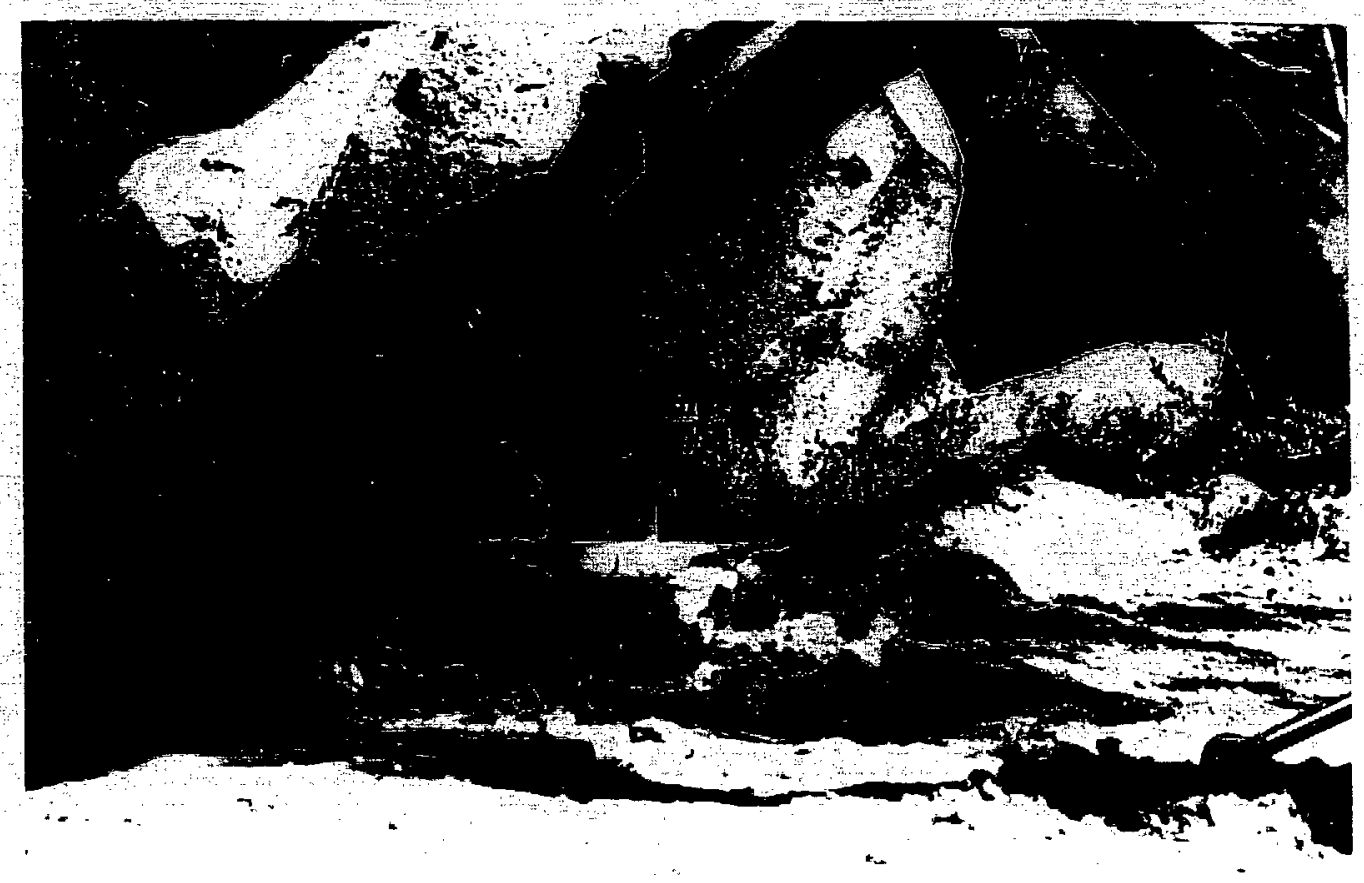

Fig. 6 B. Fxcavation by backhoe to expose the structure.

FIg. 6. Decomissioning operations at $\mathrm{TA}-2-32$, an underground chamber. 


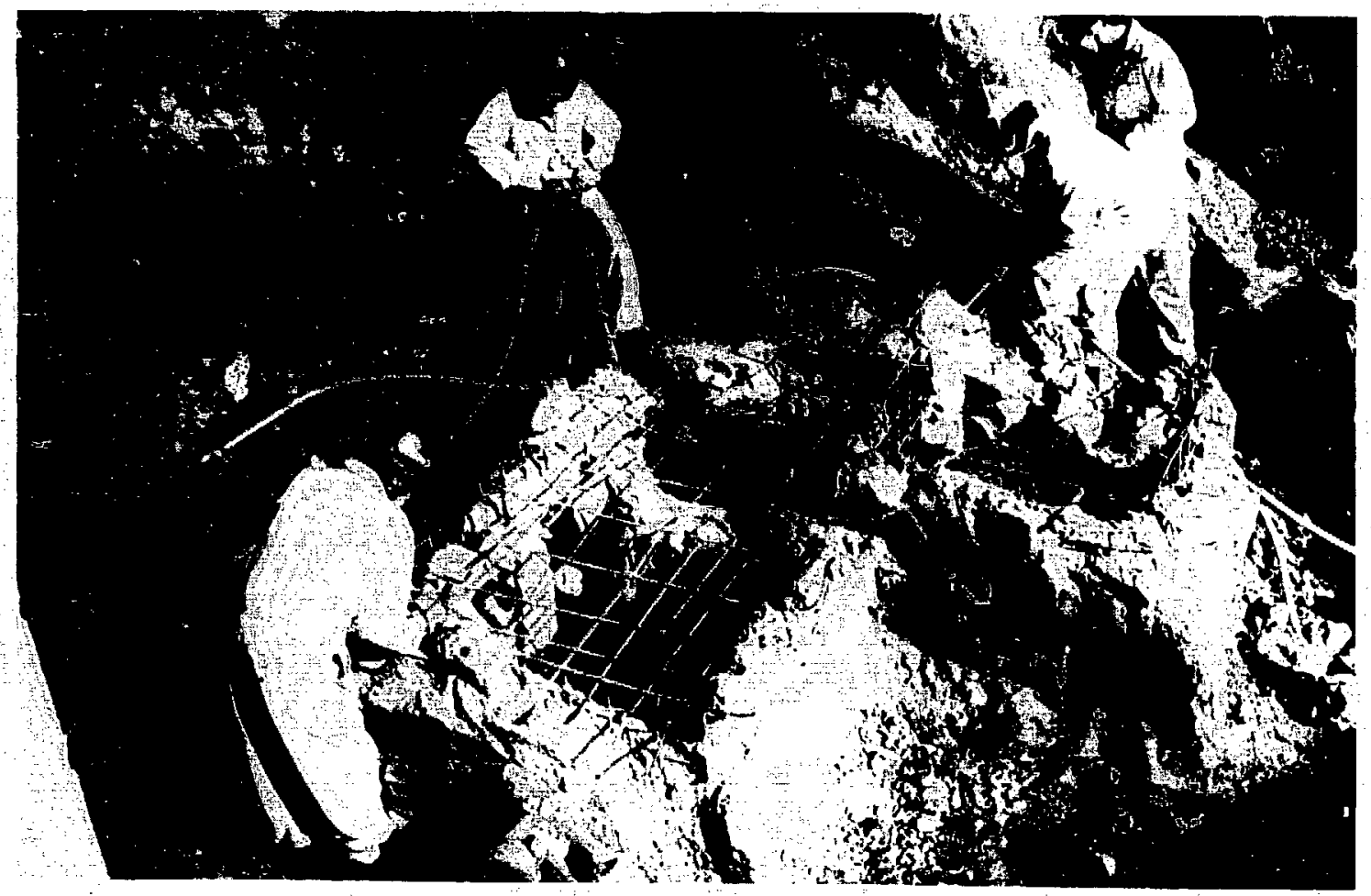

FIg. 6 C. Reducing the structure by jackharmering.

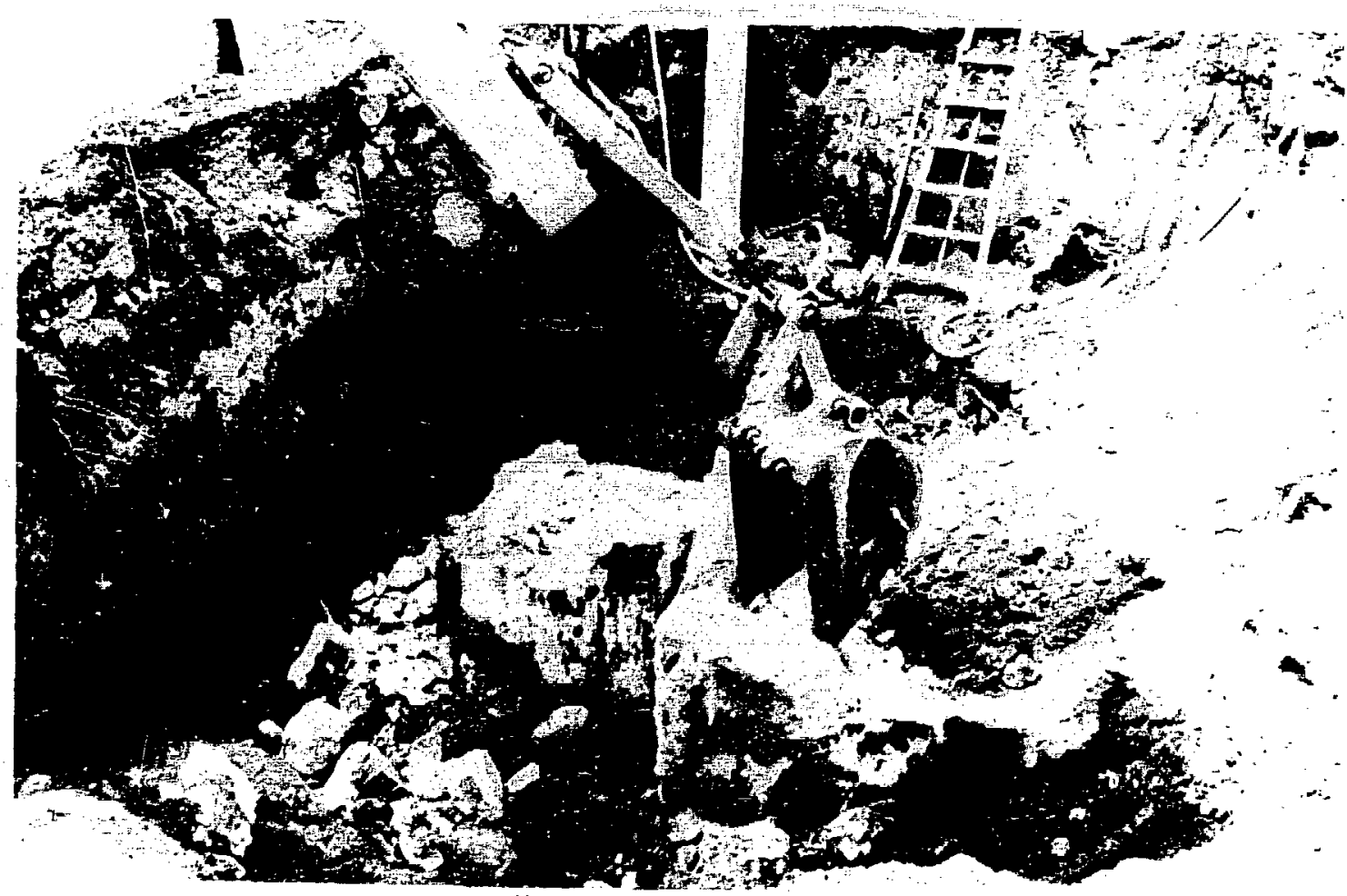

FIg. 6 D. Removing floor sections by backhoe. 
5. TA-2-43, A Sept1c Tank. Samples of the water overflowing this sept1c tank and a sludge sample from 1ts bottom showed no detectable activity (alpha or beta/garma). The source of the water was verifled by dye tracer to be infiltrating spring water being pumped from the basement of TA-2-1. Dye tracer in an unmarked sink in the reactor room did not come to TA-2-43. A 6-1n, clay p.pe from the TA-2-1 basement was rerouted by teelng off a 6-1n. white PVC pipe from a location near TA-2-43 directly to the stream a few feet downstream of the concrete debris catcher (TA-2-39) (see Flgure 7). HSE-8 reviewed the environmental implications of this previously unknown discharge and 1ssued an NPDES* permit to document its existence.

Removal of TA-2-43 is shown in Figure $8 \mathrm{~A}$ and $\mathrm{B}$. Its dimensions were $13 \times 8 \times 6 \mathrm{ft}$ with walls $6 \mathrm{in}$. thick. This structure was also jackhammered into smaller pleces to permit removal.

An unnumbered 6-1n. clay line drained the sept1c tank overflow to the stream. This line was removed from depths of 3-8 $\mathrm{ft}$ where 1t angled across the area east of the septic tank. This same area was worked extensively later to remove spots of contamiriation detected on the surface. This activity was not detected at the time the clay line was removed.

6. Effluent Line and Delay Tanks. Line 117. Approximately $230 \mathrm{ft}$ of Line 117 was removed between TA-2-1 and TA-2-19 at a depth of 6-7 ft. None of the soll samples from the trench showed activity concentrations above de minimus levels. Concrete shleld blocks and lead plates had been used to shleld Line 117 over 1ts length to 30 ft east of TA-2-1. A large rock above the line required that a 20-ft section be removed using a pipe pulling device.

*NPDES is National Pollutant Discharge Elimination System. 


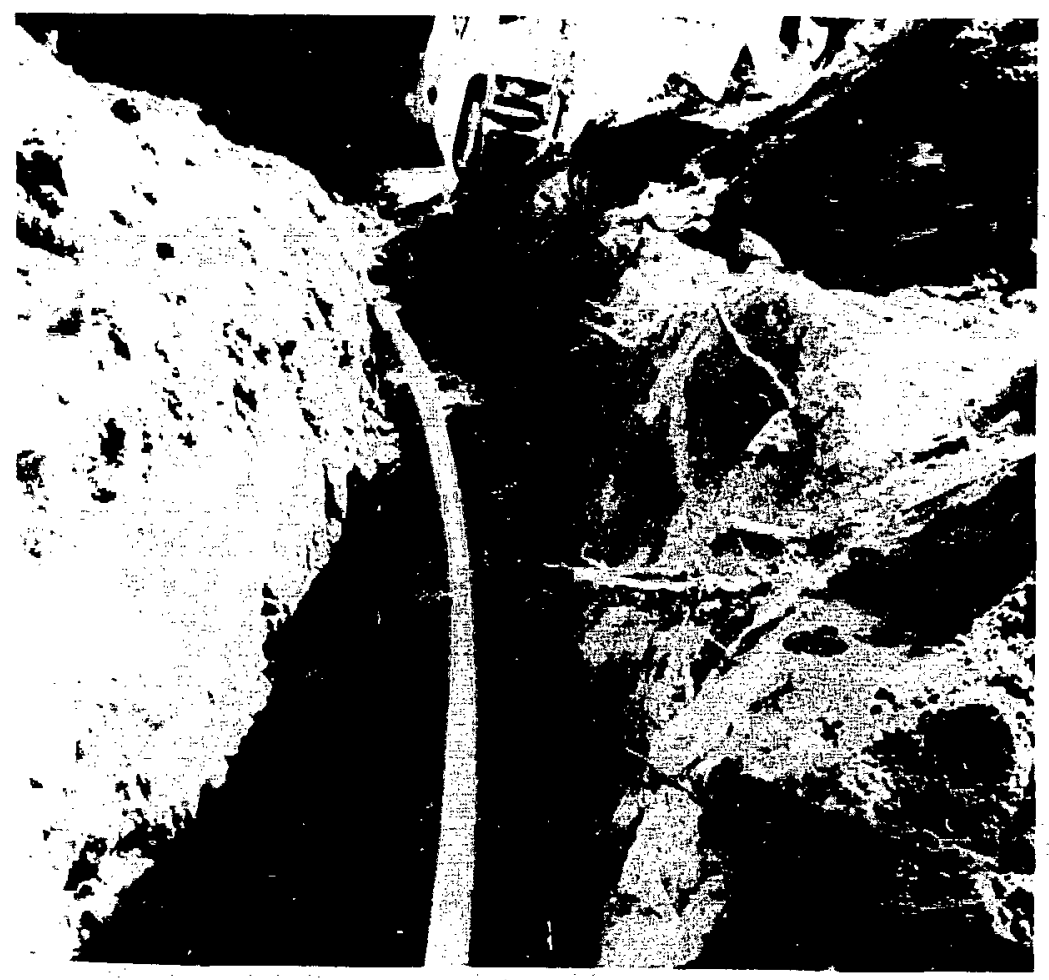

Fig. 7. Relocation of plastic pipe carrying inflitrating water fron the TA-2-1 basement. 


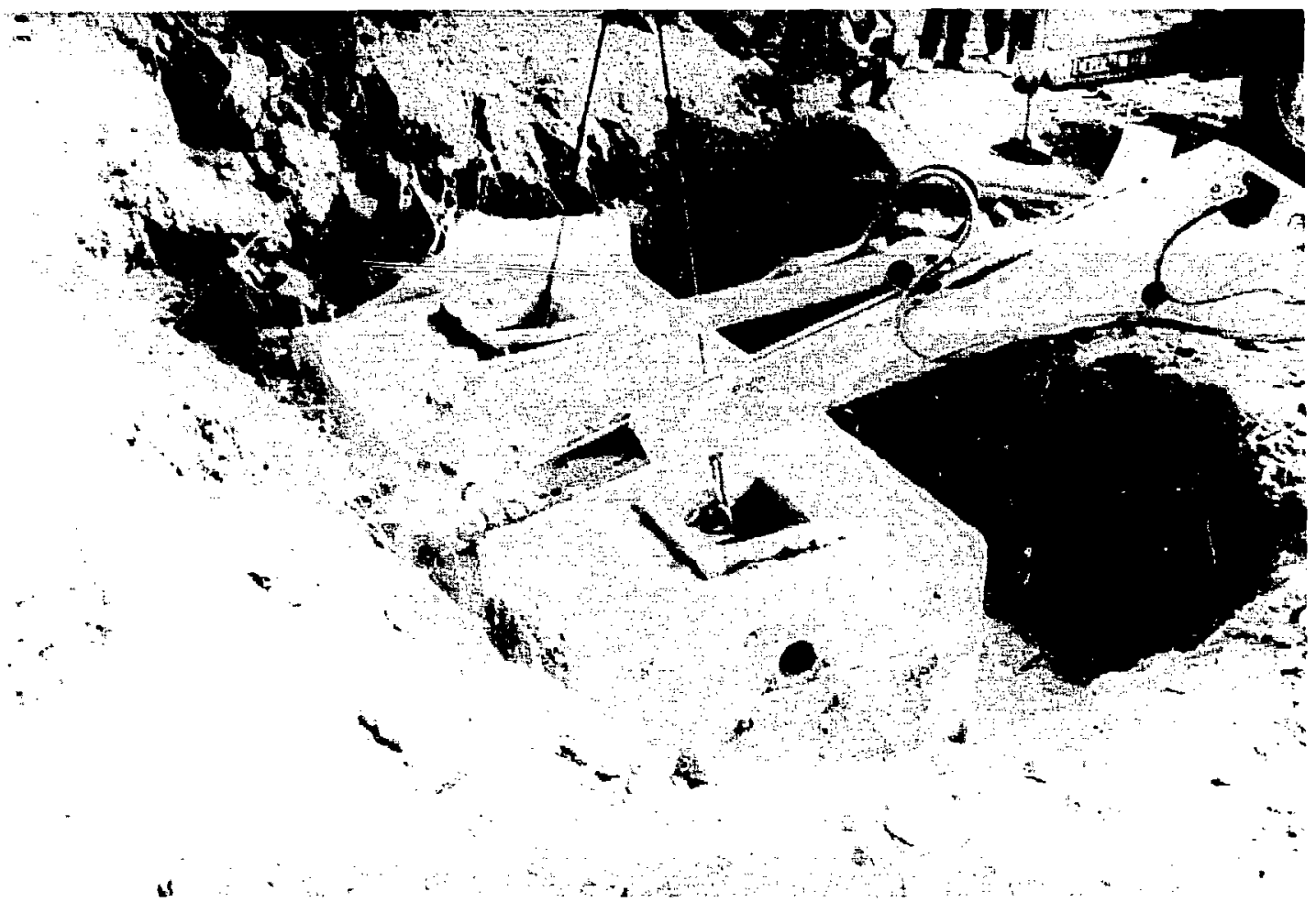

FIg. 8 A.

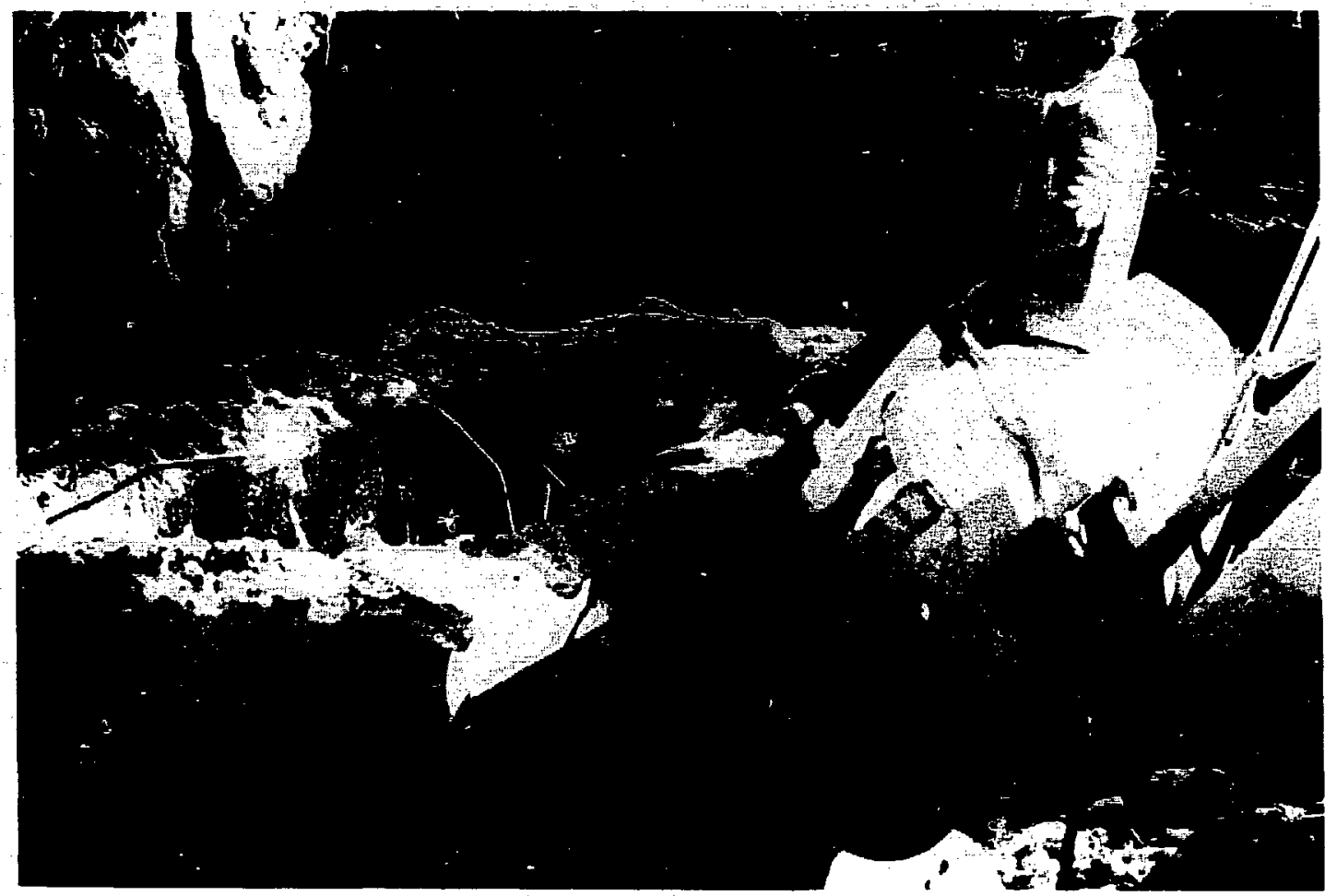

F1g. 8 B.

Fig. 8. Removal of TA-2-43, a sept1c tank. 
Approximately $40 \mathrm{ft}$ of Line 117 will remain inside TA-2-1

from the east entrance to the pit near the reactor.

Line 118. Removal of this sma11-dlameter 11ne required no excavation. It was pulled from shallow burlal w1 thout diffculty and sent to TA-54.

Line 119. Approximately $205 \mathrm{ft}$ of the 3-1n. stainless steel gaseous effluent line was removed from depths ranging from 2 to $9 \mathrm{ft}$. Near TA-2-48, 1ts depth was approximately $9 \mathrm{ft}$, which was deep enough to be in ground water. The excavation was pumped by a small trash pump to allow cutting and pulling the line. Contact readings along this portion of the pipe ranged from 4 to $35 \mathrm{mR} / \mathrm{hr}$. A soll sample showed no activity at that location. This was the same general area near TA-2-48 where sampling later showed ${ }^{137}$ Cs activity up to 1.2 $\mathrm{nCl} / \mathrm{g}$, Indicating that extensive contamination existed at the time of this work. It may have been either preexisting or spread by the pipe-pulling operation. Removal of this contaminated soll is discussed further under TA-2-48 removal.

Item 131, Delay Tanks. The delay tanks were found approximately $4 \mathrm{ft}$ underground. They were not a large radiation source ( $8 \mathrm{mR} / \mathrm{h}$ at contact, maximum). Their connection to the Omega West vent line was plugged by threaded cap. Soll sampling under the tanks showed no radioactivity.

7. TA-2-48, A Condensing Trap. This condensing trap/manhole stmucture was worked on in two perlods. The first, in October 1985, accomplished removal of the manhole which was belleved at the time to be the superstructure of a rather large (24-1n.-dlam x 12-ft-long) condensing trap (see Ios Alamos drawing ENG-C-1718). The manhole was a concrete structure $5 \times 5 \times 7 \mathrm{ft}$ with 8-1n. walls and steel cover doors (see Flgure $9 \mathrm{~A}$ and $\mathrm{B}$ ). No activity was detected inside the 


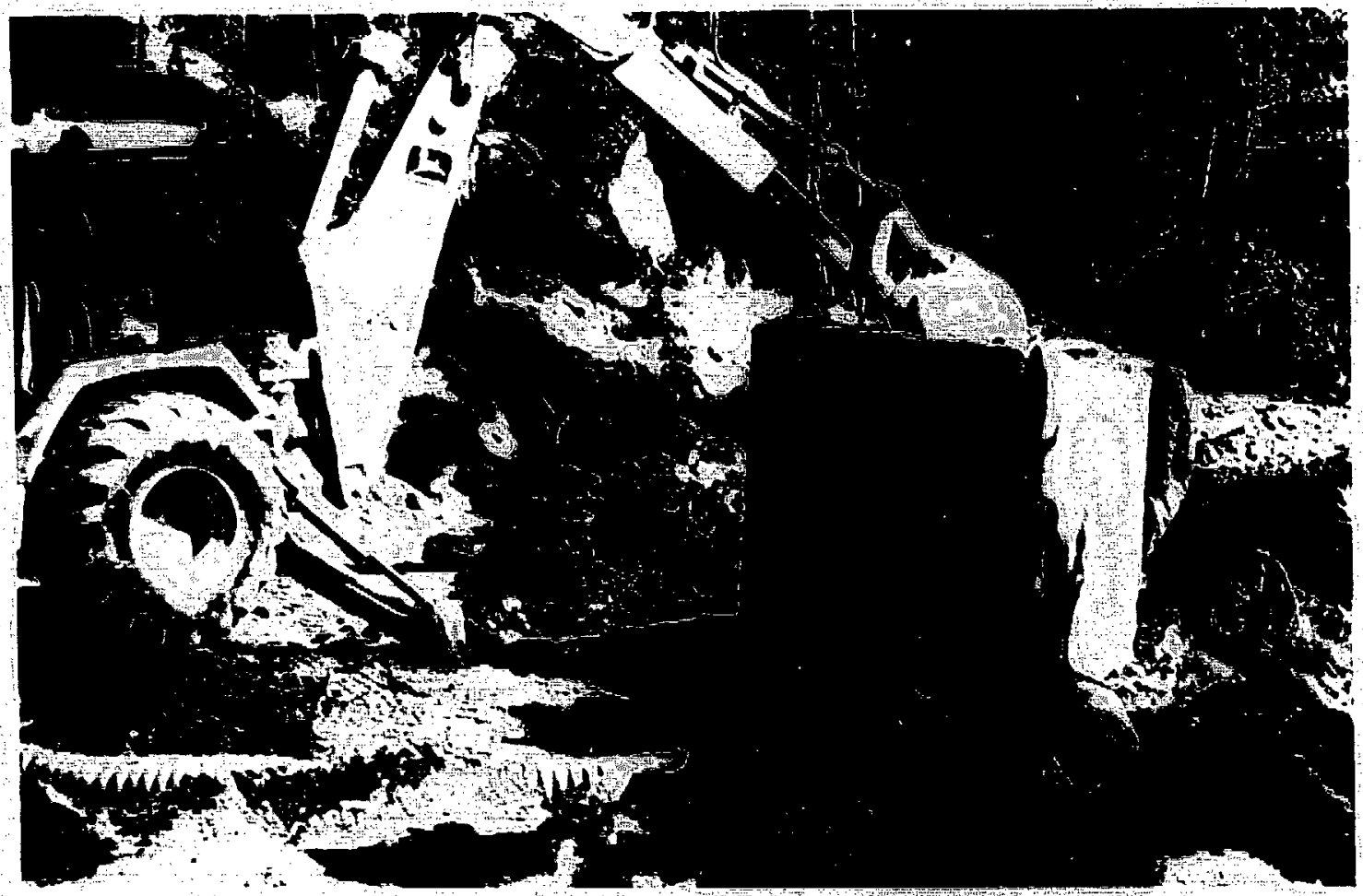

FIg. 9 .

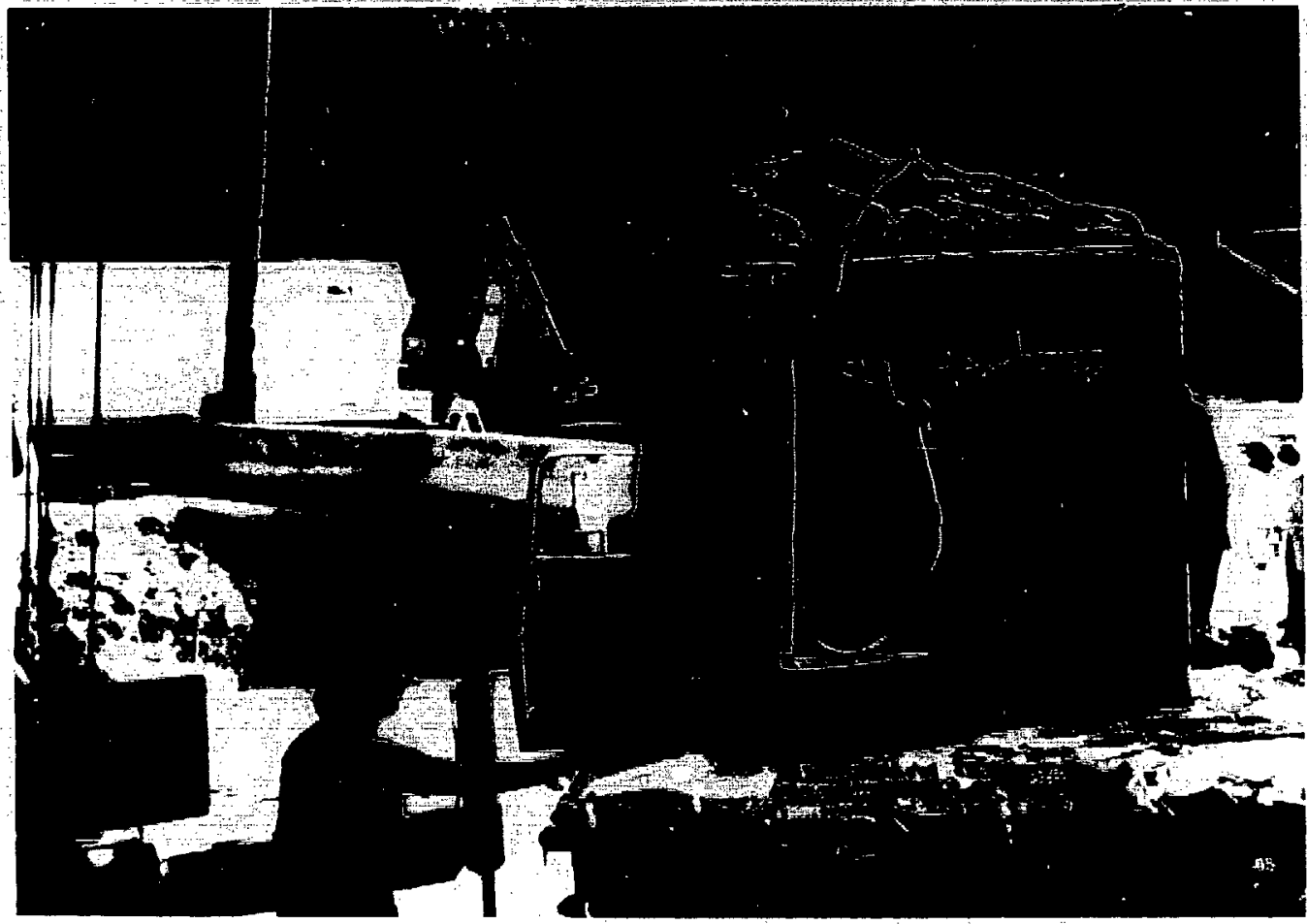

FIg. 9 B.

FIg. 9. Removal of TA-2-48, a condensing trap. 
manhole. Approximately $5 \mathrm{ft}$ of $3 / 4-1 \mathrm{n}$. stainless steel pipe was protruding a few feet from the bottom of the manhole. At the time, this was not considered the working portion of the trap. It was learned later that this small diameter pipe was the standpipe by which liquid had been removed from the low point in Line 119. This procedure had been used throughout the latter years of Water Boller operation.

Components of the condensing trap (TA-2-48) belleved to be under the manhole could not be removed due to infiltrating ground water. The stream was approximately $10 \mathrm{ft}$ away. Water from the stream and spring water from the north side rapidly filled any excavation when it reached a level 2-3 ft below stream level. Because the components could not be observed nor grappled for adequately, further operations were postponed unt1l drier conditions. May and June are typically dry months, falling between spring runoff of snow melt and the high frequency of thundershowers in July and August.

Operations resumed June 16, 1986, after no improvement in underground water level was observed at an observation well nearby. Stream flow was also higher than normal for June. A removal plan was devised by which the upper end of the suspected condensing trap would be exposed and infiltrating water would be pumped away by a large-capacity (10,000 gal./min rated) trash pump. Th1s would allow examination of the trap and a determination could be made of 1ts ab1lity to retain any radioactivity left in 1t. However, unexpected cesium contamination up to $1200 \mathrm{pCl} / \mathrm{g}$ was detected in spots of contamination on the surface before operations started. Th1s prompted an altemative plan by which a secondary pit was dug on the south slde of the stream to recelve potentially contaminated water pumped from the primary p1t at the TA-2-48 location. Ces1um-137 was 1dentified as the only significant radionuclide present. HSE-1 and HSE-8 representat1ves agreed that water from the primary pit would not be 
discharged directly to the creek. Water would not be discharged from the secondary p1t unless sampling showed it to be under $40 \mathrm{nCl} / \mathrm{L}$, wh1ch would not exceed the $3 \mathrm{nC1} / \mathrm{L} 11 \mathrm{mit}$ for offsite discharge once stream dilution was taken into account. (Discharge from the secondary pit was not needed.) Water activity in the primary pit, which showed rapld water infiltration from all sides once 1 ts depth was 2-3 ft below stream level, ranged from 10-30 $\mathrm{nCl} / \mathrm{L}$ during digging but decreased to 1-2 nC1/L after t1me was allowed for sedimentation. This confirmed earlier environmental reports that ${ }^{137} \mathrm{Cs}$ activity would be associated with sediment in the alkaline solls of Los Alamos Canyon. The sediment was readily filtered out by percolation to soll from the secondary pit. The secondary pit was then decontaminated later by removing a few inches of soll from its sides and floor.

June 17 to June 26, 1986, was a per1od of unusually heavy rainfall (June total was a record $5.67 \mathrm{in.}$ ). The flrst heavy rain following resumption of operations prompted rerouting the stream approximately $6 \mathrm{ft}$ further away from the TA-2-4R location. This involved constructing a temporary dike (see Figure $10 \mathrm{~A}$ ) to prevent erosion by the stream into the contaminated area. Several heavler rains followed. Stream erosion into the TA-2-48 area was controlled through the pertod.

Excavation of the primary pit was approached very carefully to avold breaking into the suspected condensing trap unt1l Its containment capability and 1ts activity content were better known. Not unt1l the primary pit had been pumped down by the large trash pump was it leamed that only the base plate connected to a 2-ft section of the 24-in.-diameter condensing trap remalned (see Flgure $10 \mathrm{~B}$ ). The top $10 \mathrm{ft}$ of Its length had been cut away by cutting torch and the base left in place for unexpla1ned reasons. The base contalned activity, as indicated by a $50 \mathrm{mR} / \mathrm{hr}$ contact reading. Also 
found in the primary pit was a length of 3-1n. stainless steel tubing attached to a large plece of concrete (see Figure $10 \mathrm{C})$. Th1s tubing was approximately $10 \mathrm{ft}$ long with a reducer (3-1n. to $1-1$. diameter) on one end and an elbow near the other end. These features resemble the connecting Ine between the gaseous effluent line and the condensing trap shown on a 1948 drawing (see FNG-C-1718). The large area excavated and the pleces removed give reasonable assurance that all components of the two condensing traps have now been removed.

The source of the ${ }^{137}$ Cs contamination was considered. It was found in unexpected places where it should have been discovered in earlier operations. The only explanation presently available is that the contamination was in spots spread over a large area. Soll sampling locations on a 20-ft grid for the initial survey obviously missed the more active spots. Although the $0.663 \mathrm{MeV}$ photon of ${ }^{137} \mathrm{Cs}$ is easy to detect with portable GM instruments, the spotty activity might be detected only by diligent surveying.

The gaseous effluent line and the base of the original condensing trap were obvious sources of contamination. Contamination from any plpe below ground water level could have been spread in the one or two locations where the plpe snapped as it was physically pulled from the ground. Contamination from the base was relatively free to be washed out, although a sediment sample taken from the pit after its removal was not excessive $(420 \mathrm{pCl} / \mathrm{g})$. No spots in the TA-2-48 area were found measuring above $1200 \mathrm{pCl} / \mathrm{g}$. A possible source of surface contamination which is suspected but not verifled-1s that excess condensate was disposed of on the ground (Improperly by today's standards but perhaps not considered so in the late 1940s). This would explain the rather high, spotty nature of the contamination which over the years 


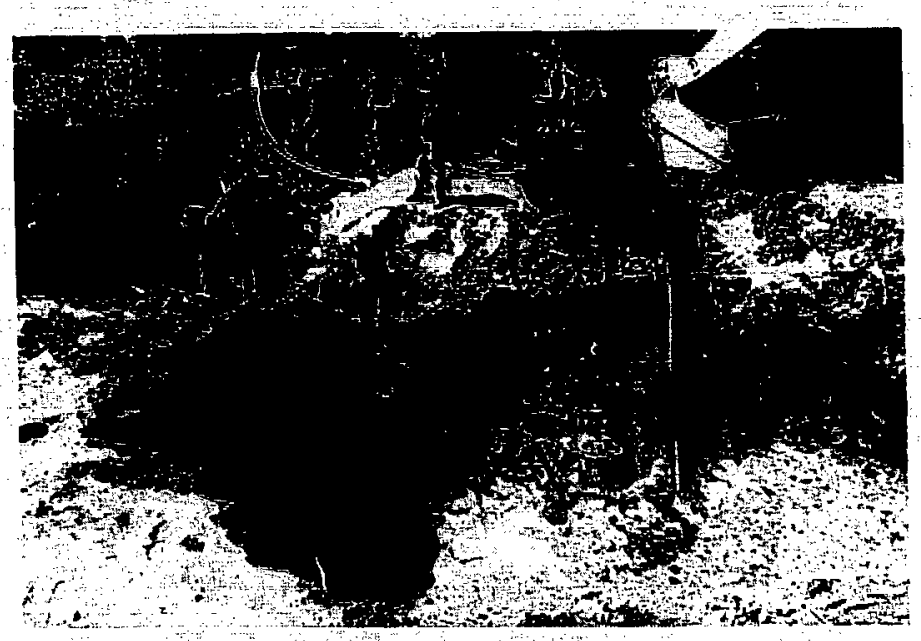

F1g. $10 \mathrm{~A}$.

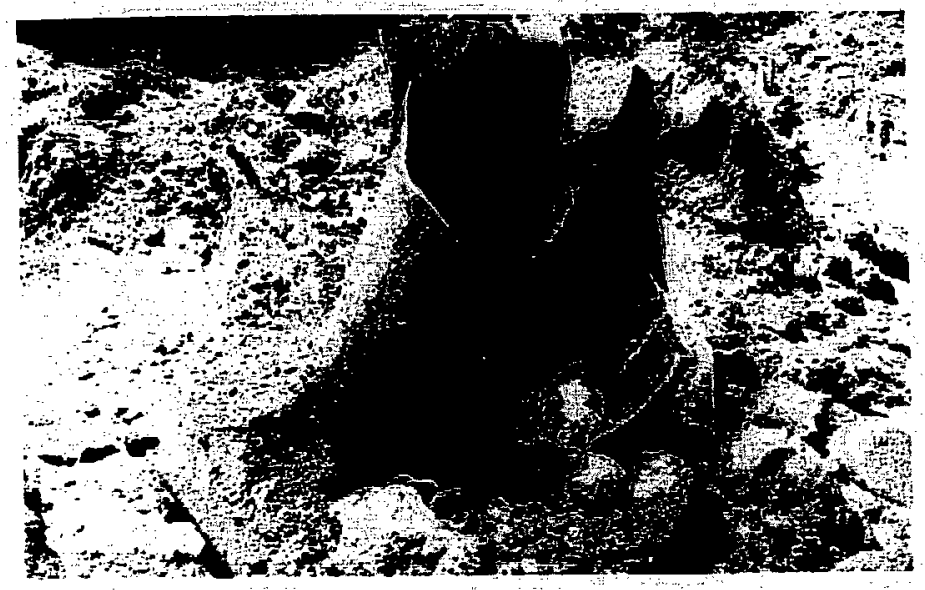

Fig. 10 B.

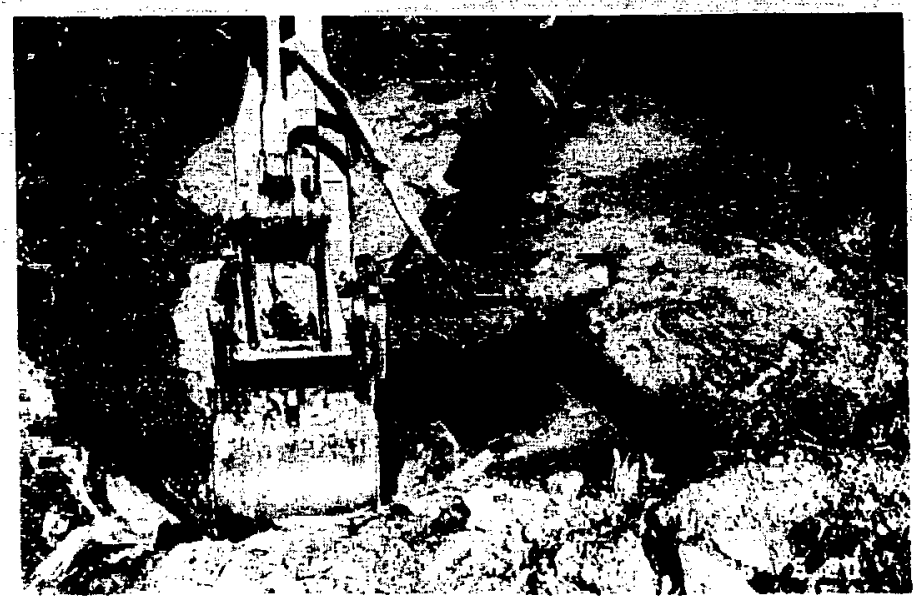

Fyg. $10 \mathrm{C}$.

F1g. 10. V1ews of operations during component removal at TA-2-48, the condensing trap. Top view shows the trash pump resting on the dike separating the primary pit and tie stream; other views show components removed from the primary pit. 
has not moved very much, considering low sediment concentrations $(<10 \mathrm{pC1} / \mathrm{g})$ in the stream bed 100-200 feet downstream.

FInal radioactivity concentration in the soll at the TA-2-48 location was $1000 \mathrm{pCl} / \mathrm{g}$ left at a depth greater than $5 \mathrm{ft}$ (much of the area was left under $7 \mathrm{ft}$ of clean fill). Flgure 11 shows the general. location of the highest concentration left subsurface at the TA-2-48 location. A few locations in the surface layer (within $5 \mathrm{ft}$ of the surface) were known to be silghtly above the de minimus level but were within the concentration gulde of $75 \mathrm{pCl} / \mathrm{g}$. Stablilzation of the stream bank by a line of riprap (boulders and smaller rock) and reseeding with western wheat grass was accomplished to prevent erosion into the area.

ALARA Decision. Fconomic reasons made $1 t$ unlikely that all contaminated soll could be removed to de minimus level in the TA-2-48 area. Additional funding of $\$ 40-50 \mathrm{~K}$ would he needed to finish the TA-2-48 location alone. Representatives of HSE-1, HSE-8, ENG-1, and Zla (now Pan Am) participated in a closure decision which was considered to meet ALARA policy, thereby providing reasonable assurance that the health and safety of employees and the public would be protected over the long term. As recorded by ALARA memorandum (Elder to Distribution, HSE-1-JE-20, June 5, 1985), the following steps were taken to reach closure of the area and prevent erosion into suhsurface soll which contains radioactivity $(1000 \mathrm{pCl} / \mathrm{g}$ is considered representative of maximum subsurface concentration in this area).

a. The TA-2-48 area (then at about stream level) was worked with soll removal equipment until no hotspots were found or until the ground water level was reached. Soll in the area inmediately above the primary pit was removed down to water level. 
b. The stream channel was straightened opposite the primary pit and its north bank was stabilized with riprap (large boulders and smaller rock).

c. HSE-8 performed a radiological survey of the area before backfilling.

d. The TA-2-48 area north of the stream was covered with at least $5 \mathrm{ft}$ of clean crushed tuff, which has supertor erosion resistance to ordinary soll. Contouring and reseeding were carried out as HSE-8 recommended.

e. HSE-8 would continue long-term monitoring of Los Alamos Canyon water and sediments to assure the adequacy of the project, as described in Section IV.D. above.

B. Other Contaminated Areas at TA-2.

F1gure 11 shows locations where surface actlvity was detected and a cleanup effort was initiated. Additional funding ( $\$ 36 \mathrm{~K}$ from SFMP and $\$ 4 \mathrm{~K}$ of local funding) was applied to these areas. Major contamination was found in the North-East area. The period July 10 to September 26, 1986, was spent resolving the contamination problems in these areas.

1. North-East Area. The North-East area was initially known to contain numerous spots of beta/gamma emitting surface contamination which ranged from $100 \mathrm{pCi} / \mathrm{g}$ to $5 \mathrm{nCi} / \mathrm{g}$. One spot almost in the stream was measured by Ludlum Model 3 endwindow GM detector at $15000 \mathrm{cpm}$ (approximately $4 \mathrm{mR} / \mathrm{hr}$ ) with the source being an undetermined distance below the surface. This spot was (perhaps coincidentally) very near the outfall for the TA-2-43 septic tank overflow pipe. The decontamination operations were conducted in a manner that would avoid spreading contaminated soll into the stream. In general, this approach was to draw soil away from the stream; where activity was below ground water level, th. stream would be 


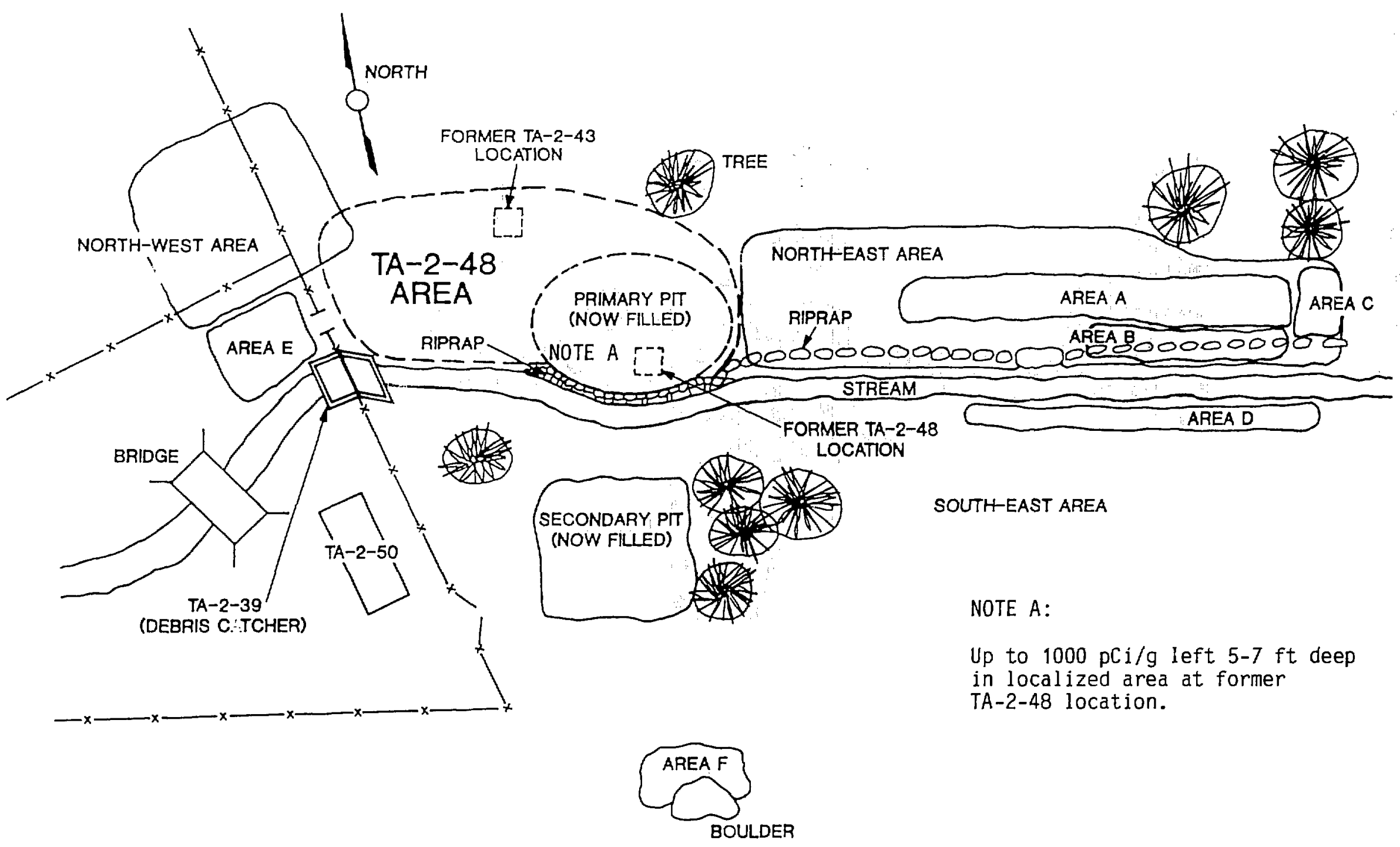


diked with clean soll and contaminated wet soll would be placed in a secondary location to dry or to be mixed with dry soll as necessary to allow transport without dripping to TA-54.

The John Deere backhoe and the Llebherr excavator were used to remove a large pine tree and several smaller trees and undergrowth. Several large bculders were removed due to contamination which could not be removed without scabbling.

Three major areas of interest were encountered in the NorthEast area which required leaving some contamination near or slightly above de minimus levels (25 pCl/g surface and 75 $\mathrm{pC1/g}$ subsurface). These areas, designated A, B, and C, are shown in Flgure 11 and discussed below.

AREA A. Two contaminated lengths of 6-1n.-diameter VCP (34-ft and 20-ft sections separated by a gap) were uncovered approximately $24 \mathrm{in}$. below the route of the TA-2-43 septic tank drain pipe removed in October 1985. The arrangement of rock and sand around these pipes and uniform soll contamination in the area suggests that a leach fleld existed at some time in Water Boller Reactor operation. A chemical waste treatment shack east of the reactor bullding was recalled by a veteran operator as a possible source of material disposed of in the leach field. The contamination found in the pipe sections and adjacent soll was a mixture of alpha and beta/ ganma emitters, the alpha emitter primarily being ${ }^{235} \mathrm{U}$ fuel. Cross trenching along the probable path indicated that the sections found were probably the only sections left after earlier removal operations. Initial activity at this location was 2-4 $\mathrm{nCl} / \mathrm{g}$ detected in a spotty array over an area 83 $\mathrm{ft} x 22 \mathrm{ft}$. At 1 ts nearest point, the stream was about $10 \mathrm{ft}$ away from this area. After removal of soll down to ground water level, the remaining concentration of beta/ganma emitters was measured to be 53-67 pC1/g w1th no alpha emitter 
remaining. These samples were taken 6-8 ft below the orig1nal grade. The area was backfilled with clean tuff after consultation with HSE- 8 . The activity left in Area $A$ is discussed below under ALARA Decisions.

AREA B. This area was nearest the stream and contained the 4 $\mathrm{mR} / \mathrm{hr}$ hotspot described earlier. Soll samples of $3 \mathrm{nCl} / \mathrm{g}$ beta/garma were taken from this area after excavation to ground water level. Greater effort was expended by excavat1ng 2-3 ft deeper and collecting the mud and water in a secondary pit at Area C. This soll was allowed to dry $24 \mathrm{hr}$, then was mixed with dry soll as needed to allow transport to TA-54 without dripping. The highest soll samples after this operation were taken at the location of the $4 \mathrm{mR} / \mathrm{hr}$ hotspot; these showed 1mprovement to $74 \mathrm{pCl} / \mathrm{g}$ beta/garma and $68 \mathrm{rm} / \mathrm{g}$ alpha. The area was backfilled after consultation with HSE-8. The activity left in Area $B$ is discussed below under ALARA Decisions.

AREA C. This area at the far east end of the contaminated area was cleaned up last after it had served as a secondary p1t for wet soll from Area B. Soll removal to ground water reduced final soll samples to 40 and $87 \mathrm{pCl} / \mathrm{g}$ beta/gamma. The area was backfliled with clean tuff after consultation with HSE-8. The activity left in Area $\mathrm{C}$ is discussed below under ALARA Decisions.

2. South-East Area. This area was across the stream from Area B. Activity near the stream was positive but generally low. A portion of the stream bank on that side was taken out as part of a stream-widening operation. Flnal soll samples in Area $D$ were less than $50 \mathrm{pCl} / \mathrm{g}$ beta/gamma, which w1ll remain as a surface concentration. 
Two local hotspots further from the stream were removed in September 1986 to complete the project. The first spot (des1gnated Area F on Flgure 11) was approximately $15 \mathrm{~m}$ east and $10 \mathrm{~m}$ south of the fence corner behind TA-2-50; the second, $130 \mathrm{~m}$ east of the fence comer. This latter location was decontaminated by removal of a length of tubing. Area $F$ was excavated to $6 \mathrm{ft}$ deep across the downhll face of a large boulder; this reduced soll concentration to below 25 $\mathrm{pCl} / \mathrm{g}$. During this operation, surveying uphill from the boulder detected other surface contamination, the highest being $273 \mathrm{pCl} / \mathrm{g}$. Removal of this soll could not be undertaken at that time due to lack of funds. The location was logged for possible future decontamination.

3. North-West Area. The North-West area included a fenced area north of the original TA-2-19 location and an area used for truck staging near the bridge. The area along Lines 117 and 119 was cleaned to de minimus levels as described earlier. The area north of the TA-2-19 location was rechecked during June-August 1986 operations and found to have several contaminated 1tems, the most notable being $30 \mathrm{ft}$ of $1-1 \mathrm{n}$. stainless steel pipe routed along the north-south fence. Its source and destination are unknown. Local minor contamination remains in this area but was not addressed further because it was Inside the TA-2 security fence.

The area which served as a truck staging area during decontamination operations showed minor positive activity ( 30 $\mathrm{pCl} / \mathrm{g}$ average) before a final 6-1n. layer of topsoll was applied.

ALARA Decisions. Closure operations in the North-East, SouthEast, and North-West areas provide reasonable assurance that radioactivity left in the soil is minimal and will not be a further hazard to employees, the public, or the environment. A decision regarding left contamination was recorded in an ALARA 
memorandum (Elder to Distribution, HSE-1-JF-37, September 11, 1986). These operations are belleved to meet Los Alamos ALARA policy for the following reasons:

- The cost of continuing removal of detectable radioactlvity in the area was belleved to exceed any additional benefit.

- Radioactivity in the North-Fast area was reduced to below (or only slightly above in Area $C$ ) subsurface de minimus levels (75 pC1/g alpha or beta). This area was backfilled to at least 5-ft depth.

- Radioactivity on the surface in the South-East area was near de minimus level and not deserving of extensive removal of vegetation.

- Radioactivity in the North-West area was near the de minimus level and inside the security fence.

- The stream bank was stabilized by a combination of logs and riprap along the full length of the North-East area. The stream bed was widened and straightened along the full length of this area to reduce the likelthood of washout.

- The closure of the area surface with topsoll and vegetation is expected to stabilize the 5-7 ft of backfill.

- Control over the area will be maintained. The area is outside the TA-2 fence but is approximately $6.4 \mathrm{~km}$ inside the boundary of DOE-owned land.

- Long-term environmental monitoring of the stream bed downstream of TA-2 w1ll continue, as described in Section IV.D. above.

Flgures $12 \mathrm{~A}$ and $\mathrm{B}$ show the area east of the reactor bullding, TA-2-1, at the close of Phase I operations. 


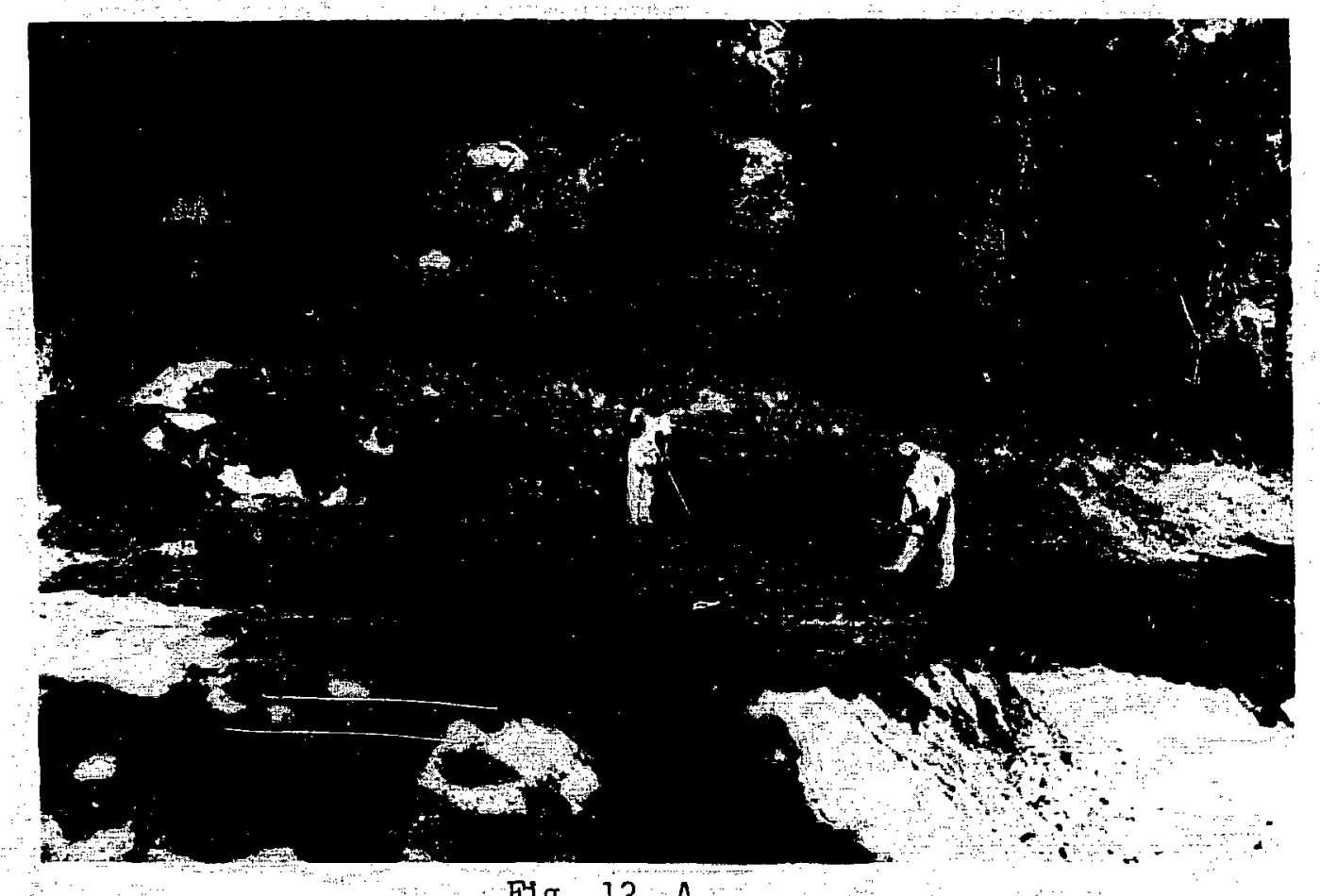

FIg $12 . \mathrm{A}$.

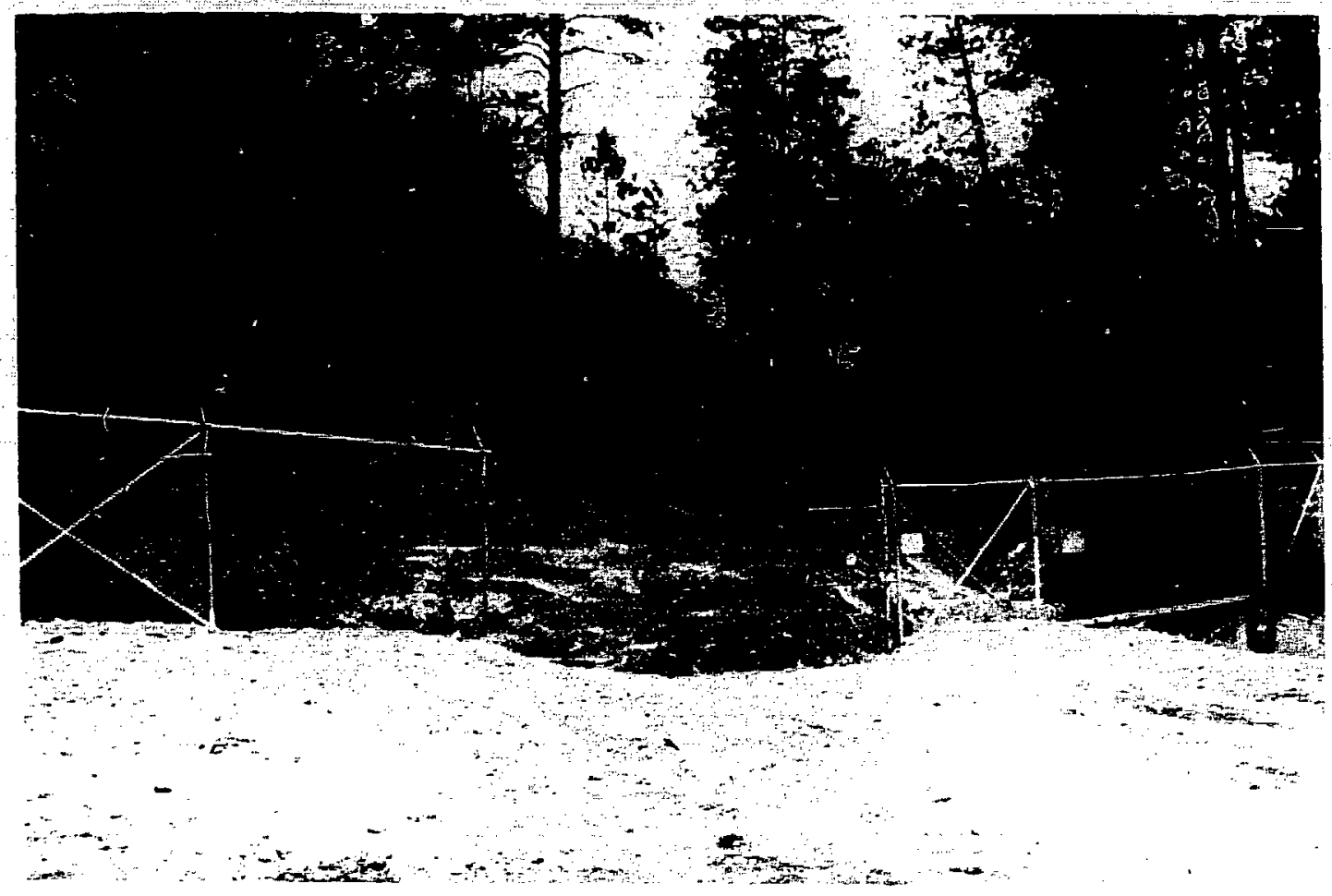

F1g. 12. B.

Fig. 12. Views of the decontaminated area, looking eastward along the stream. 
VI. SUMMARY

External structures and underground piping associated with the gaseous effluent (stack) Ilne from the TA-2 Water Boller Reactor were removed from the area east of the reactor bullding. The low-level waste volume transported to TA-54 Area G for disposal was $970 \mathrm{~m}^{3}$ or 162 truck loads. Most of this waste (approximately 120 loads) was contaminated soll. Total cost of the project was $\$ 320 \mathrm{~K}$.

Three concrete structures were removed by jackhammering into manageable pleces. Three others were removed as units. One structure (TA-2-48) presented a difficult removal problem because several of its components were below ground water. Pumping ground water from the TA-2-48 excavation to a secondary pit with a large trash pump permitted removal of all components. Radloactivity above the de minimus level for subsurface soll ( $75 \mathrm{pCl} / \mathrm{g}$ if deeper than $5 \mathrm{ft}$ ) was left at the TA-2-48 location. An ALARA decision memorandum was prepared to document this soll and to describe the efforts taken to stab1lize the area. These efforts included removal of soll to the ground water level, placing boulders and rock (riprap) along the stream bank, backfilling with clean soll to at least 5-ft depth, and revegetating the area.

Another area east of the TA-2-48 location was found to be contaminated up to $5 \mathrm{nCl} / \mathrm{g}$ with beta/gamma emitters. An alpha emitter was also present in the area, which is suspected of once containing a leach field. Its proximity to the stream required extensive removal of contaminated soll. After decontamination, soll activity exceeded the de minimus level in a few locations, as documented by an ALARA decision memorandum. Efforts to stabilize this area were similar to those for the TA-2-48 location. The stream bed was widened and stralghtened as a final measure to reduce erosion into areas where so1l contamination was left. These measures plus continued long-term environmental survelliance in Los Alamos Canyon are expected to fully control the minor contamination remaining at $\mathrm{TA}-2$. 
The authors would like to acknowledge the technical supervision provided for HSE-I by C. Lee Knoell, Gilbert M. Montoya, and Michael J. Martinez; health physics coverage by Joe A. V1g1I and Joe D. Truj11lo; environmental survelllance support by Richard Romero and Walter J. Wenzel (HSE-8); engineering support by Darrell P. Hohner (ENG-1); contractor support by Douglas Barnes and Peter Carlson (Z1a Company, now Pan Am); and historical background support by John W. Starner (INC-5). The report was capably word processed by Sandra Borrego (HSE-1).

\section{REFERENCES}

Bunker 1963: Merle E. Bunker, "Status Report on the Water Boller Reactor," Los Alamos Scientific Laboratory report LA-2854 (October 1963).

Elder 1986: J. C. Elder, E. J. Cox, D. P. Hohner, and A. M. Valentine, "Radioact1ve Liquid Waste Lines Removal Project at Los Alamos (1981-1986)," Los Alamos National Laboratory report LA-10821-MS (September 1986). 
APPENDIX

PROCEDURES FOR ALARA DECISIONS

ALARA policy is applied to decontamination and decomissioning (D \& D) activities at the Laboratory by way of

o normal efforts to keep exposure of each D \& D worker or any other worker ALARA while performing his job,

- limitations on potential exposure of workers from any radiation source left after D \& D activities, and

- limitations on potential exposure of any member of the public from any radiation source left after $D$ \& $D$ activities.

Implementation of ALARA activities is directed by HSE-1 (Radiation Protection Group). Oversight or enforcement is provided by HSE- 8 (Environmental Survelllance Group) when the project or activity could have a potential impact on the environment or has a human/environment interface.

ALARA activities are not directed by committee at Los Alamos. HSE-1 personnel responsible for monitoring operations involving radiation or radioactive material of a particular site advise the operating group on how best to perform the work in a manner that keeps doses ALARA.

ALARA applications have been common in D \& D work at Los Alamos. D \& D workers have had very low dose acquisition compared to radiation workers. Our experience shows that routine radiation protection practices (radiation monitoring, dosimetry, and airborne contamination sampling) and the relatively low dose rates encountered in $D$ \& $D$ operations to date combine to keep dose levels low. An HSE-1 health physics techniclan is assigned full time to D \& D projects.

ALARA decisions related to $D$ \& $D$ work at Los Alamos have dealt primarily with left contaminated items or soll. The general procedure followed to arrive at ALARA decisions for left 1tems is as follows: 
1. The HSE-1 representative is informed by the construction engineering representative that an item should be left in place for substantive reasons: it is beneath or encased with major utility lines, it is beneath structures or streets, it is at depths too great to reach by normal means. Extra effort to remove the 1tem would exceed cost/ benefit guldance.

2. The HSE-1 representative verifies that the quant1ty of remaining radioactivity is either low enough or its depth is great enough that the Item will not pose a hazard to workers or the public anytime in the future. Entombment or placarding or placement of a monument is considered in cases where intrusion by digging into the area could be hazardous.

3. The HSE-8 representative is informed of the need to leave the item in place. He investigates and concurs or asks for further effort.

4. When concurrence is reached, the HSE-1 representative prepares an ALARA memorandum and includes descriptive material as needed to document the location and activity level of the item. 